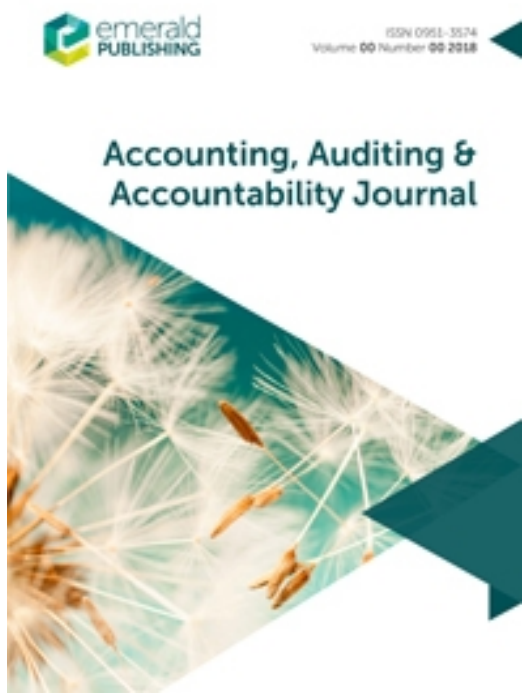

Accountability and governance in implementing the Sustainable Development Goals in a developing country context: Evidence from Tanzania

\begin{tabular}{|r|l|}
\hline Journal: & Accounting, Auditing \& Accountability Journal \\
\hline Manuscript ID & AAAJ-10-2019-4220.R4 \\
\hline Manuscript Type: & Research Paper \\
\hline Keywords: & $\begin{array}{l}\text { Accountability, From government to governance, Governance, Meta- } \\
\text { governance, Sustainable Development Goals, Tanzania }\end{array}$ \\
\hline \multicolumn{2}{|l}{} \\
\hline
\end{tabular}




\section{Accountability and governance in implementing the Sustainable Development Goals in a developing country context: Evidence from Tanzania}

\section{Abstract \\ Purpose}

This paper examines the accountability and governance mechanisms and the challenges in a multi-stakeholder partnership seeking to implement the Sustainable Development Goals (SDGs) in a developing country (DC), namely Tanzania.

\section{Design/methodology/approach:}

The paper draws on work on the shift from government to governance to meta-governance to examine the SDGs framework's governance regime. The data stems from documentation, focused group discussions, and face-to-face interviews with key stakeholders involved in the localisation of SDGs in Tanzania.

\section{Findings:}

Despite the emphasis given by promoters of SDGs on the need for multi-stakeholder engagement, and network and market-based governance, Tanzania's hierarchical governance framed in national legislations dominated the localisation of the SDGs. The national-level meta-governance structures were somewhat dysfunctional, partly due to a lack of welldesigned coordination mechanisms for collaborative engagement with key stakeholders. The limited involvement of different meta-governors, and particularly network and market-based governance arrangements, has had severe implications for achieving the SDGs in DCs in general and Tanzania, in particular.

\section{Originality/value:}

Focusing on Tanzania, the paper sheds light on how context in DCs, interactions between state and non-state actors, modes of governance and accountability mechanisms shape the localisation of SDGs and realising the SDGs' agenda. The implementation in Tanzania focused on priorities in the development plan, thereby neglecting some important SDGs. This raises doubts about the possibility of meeting the SDGs by 2030. The localisation of SDGs remained within the top-down governance structure, as Tanzania's government failed to enact the policy and strategy for multi-stakeholder partnership consistent with the SDGs' principle of 'leave no-one behind'. Consequently, meta-governors' efforts and ability to monitor and demand accountability from the government was constrained by the political context, the governance system, and regulations enacted to side-line them.

\section{Practical implications:}

The paper calls for a more explicit SDG policy and strategy, alongside strengthening institutional structures and related governance arrangements in Tanzania, to promote the realisation of the SDGs. For the SDGs framework to succeed, we suggest that, in addition to adopting SDG friendly policies, the Tanzanian government should devise plans for financial resources, strategies for empowering and engaging with key stakeholders, and promote an integrative governance system that underpins accountability at the local level.

Keywords: Accountability, developing countries, from government to governance, governance, meta-governance, Sustainable Development Goals, Tanzania 


\section{Accountability and governance in the implementing Sustainable Development Goals in a developing country context: Evidence from Tanzania}

\subsection{Introduction}

[w] e .... need new mechanisms to ensure accountability - the accountability of state to their citizens, of states to each other, of international institutions to their members and of the present generation to future generations. Where there is accountability we will progress, where there is none we will underperform" (Müller, 2006, p.293).

Central to this call is the nexus between accountability and governance, particularly how accountability processes can assist a transition towards global sustainability. Accountability is deemed to be a cornerstone of governance that guides, controls, and legitimises state and non-state agencies' exercise of authority (Woolgar and Neyland, 2013). Our focus in this paper is on governmental level/public sector governance and accountability. The importance of the relationship between accountability and governance has been stressed in numerous international policies promoting global sustainability, and by international financial institutions such as the World Bank and the Intergovernmental Panel on Climate Change. The quest for accountability is also visible in the recent United Nation's (UN) agenda for sustainable development, from which the Sustainable Development Goals (SDGs) emerged (United Nations, 2015).

The SDGs' 17 goals and 169 targets, endorsed by 193 UN member states in September 2015, replaced the previous Millennium Development Goals (MDGs) ${ }^{1}$ and stimulate actions for these to be met over the next 15 years (United Nations, 2015). The lack of systemic and thorough governance and accountability mechanisms was considered a major flaw of the MDG process and a key reason for shortfalls in their achievement (Breuer and Leininger, 2021). Consequently, the SDGs, built on the scaffolding of global sustainability, sought a global governance framework for addressing major contemporary humanitarian and ecological challenges such as hunger and poverty, loss of biodiversity, environmental degradation and global climate change, natural disasters and conflicts (Bebbington and Unerman, 2018, 2020; UNRISD, 2016). The SDGs' framework set specific outcomes to be achieved and provides a basis for monitoring and reporting at the national level to secure accountability (United Nations, 2015). However, scholars claim that pursuing and realising the SDGs is not merely a matter of transferring an implementation strategy from a global to a national level (Abhayawansa et al., 2021 p.4) but requires accountability mechanisms at the national level for holding government and other societal actors to account and ensuring that targets are met (Bowen et al., 2017).

Strong governance structures and public accountability processes are critical to the national implementation of SDGs (Meuleman, 2018; Abhayawansa et al., 2021), especially in developing countries (DCs). Yet, we know little about the nature of accountability and governance mechanisms at the national level, and their impact upon the dynamics of implementing SDGs in DCs such as Tanzania. Bowen et al. (2017) for example, identify accountability as a major governance challenge and claim it needs systems for monitoring progress at the country level. Accounting scholars have problematised the paradox of accountability and sustainability governance in contemporary society (Barrett et al., 2020; Bebbington and Unerman, 2018, 2020; Charnock and Hoskin, 2020; Hopper, 2019; Niles and Moore, 2020; Sobkowiak et al., 2020). However, there has been relatively little exploration of the relationship between accountability and governance in pursuing and attaining SDGs

\footnotetext{
1 Unlike the MDGs, which focused on poverty reduction in DCs, the SDGs are characterised as universal, transformative, and integrative to all countries, not just DCs (Gabay and Ilcan, 2017).
} 
(Abhayawansa et al., 2021; Breuer and Leininger, 2021), especially at the local level, and its challenges in a DC context. Given the challenges encountered during implementations of the MDGs and the limited success of previous pro-poor development initiatives, structured through hierarchical top-down regimes in DCs (Word Bank, 2005), localization ${ }^{2}$ of the SDGs requires new forms of governance and accountability mechanisms at the national level to address their pressing socio-economic and environmental issues (United Nations, 2015; UNRISD, 2016).

A strong case has been made for adopting integrative forms of governance, whereby governments collaborate and work in partnership with public, private sector, non-governmental organisations (NGOs) and other societal actors, when localising SDGs (UNDP, 2015; Meuleman, 2015). This entails establishing appropriate cross-sector governance that fosters interaction and collaboration among key stakeholders at all levels, and the coordination of one or more governance modes, i.e. hierarchical, network and market-based (Meuleman, 2015; Meuleman and Niestroy, 2015; United Nations, 2015). This integrated governance is based on the belief that no single actor can fully address global sustainability challenges, and that collaboration and enablement rather than hierarchical top-down or market-based models, are necessary at the local level (United Nations, 2015; UNRISD, 2016; OECD, 2015). Thus, achieving the SDGs requires a shift from government to governance to meta-governance (Gjaltema et al., 2020; Meuleman 2015; Meuleman and Niestroy, 2015). This involves incorporating effective governance systems and accountability mechanisms at the national level that facilitate the participation, empowerment, and engagement of less powerful or marginalised groups' voices; and making the public, private sector and other civil society organisations (CSOs) involved, accountable (Rothstein, 2011; World Bank, 2011).

Such an endeavour can prove difficult in many DCs such as Tanzania, which face major governance challenges due to high poverty levels, contentious leadership styles, and weak institutional structures (Lauwo et al., 2016). On the other hand, the institutions and sociopolitical environment of many DCs can provide opportunities for a wider group of actors to interact, negotiate and cooperate (Fischer et al., 2019). Hence, we examine the process of localising SDGs in a DC context, the accountability and governance ${ }^{3}$ mechanisms at the national level, and the challenges encountered in a multi-stakeholder partnership seeking to implement the SDGs. Drawing on the from government to governance work (Bell and Park 2006; Haveri et al. 2009; Rhodes 1997, 2007;), we examine whether the change from government to governance, and the suggested need to involve, and engage with, multistakeholders, materialised in Tanzania (Rhodes, 1997, 2007; Klijn, 2008; Kooiman, 2003; Sørensen \& Torfing, 2005). This framework, supplemented with concepts from the metagovernance literature, helped to analyse the governance system and modes of governing used to steer the implementation of the SDGs within a DC context and Tanzania in particular. As Meuleman (2008) has stressed, different governing styles can frame relations between actors and shape their efforts in demanding accountability and transparency. The meta-governance extension helped us to analyse the processes and structures created to support interactions between state and non-state actors and the level of multi-stakeholder collaboration. Rather than exploring how this impacted on specific SDGs or targets, the research focuses on how the Tanzanian government interpreted and operationalised the SDGs framework, how key stakeholders were involved, and how the government's policies, actions, and modes of governance and accountability impacted its implementation. The data for our analysis stems

\footnotetext{
${ }^{2}$ Here localizing means, "the process of taking into account subnational context in the achievement of the 2030 agenda from the setting of goals and targets, to determining the means of implementation and using indicators to measure and monitor progress" (UNDP, 2016b, p. 6).

3 The United Nation Development Programme (UNDP, 1997) defined governance as consisting of systems, mechanism, processes, relationships, and institutions through which groups and citizens articulate their interests, perform legal rights, recognise obligations, and resolve differences.
} 
from documents, focused group discussions and face-to-face interviews with key stakeholders involved in the localisation of the SDGs in Tanzania.

The paper contributes to the accounting literature in three ways. First, it extends the literature on governance and sustainability (Bebbington and Unerman, 2018; Bebbington et al., 2017; Charnock and Keith, 2020; Rosati and Faria, 2019; Spence and Rinalidi, 2014) through insights from a DC, namely Tanzania, on efforts undertaken (or not) to adopt an integrated approach to governance when implementing the SDGs. Second, it augments the sparse literature on how the modes of governance and accountability mechanisms may affect achieving the SDG agenda (Abhayawans et al., 2021; Meuleman, 2018), and the metagovernance challenges encountered (Bebbington and Unerman, 2018; Charnock and Hoskin, 2020; Hopper, 2019; Niles and Moore, 2021; Sobkowiak et al., 2020). We extend this literature by showing how the complex governance system and local context in Tanzania shaped its mode of governing and the accountability systems for achieving the SDGs. We found that an integrated and holistic approach was essential for localising the SDGs, but the absence of a strong meta-governance system frustrated this. Other DCs are likely to face similar problems. We also showed that currently, there is no specific strategy, policy or legal framework enacted to support the implementation of the SDGs framework in Tanzania. Consequently, its governance resides within the existing hierarchical top-down governance structures, which neglects other potentially important governance structures such as networks and markets. We also found that Tanzania's government prioritises issues prominent in the national development plan. In so doing, it has inevitably neglected some important SDGs, e.g. goal 8 Decent work and economic growth and goal 13 Climate action. The promoters of the SDGs emphasise the need for a collaborative governance network and market-oriented policies; however, Tanzania's hierarchical governance framed in national legislations has dominated how the SDGs are implemented and has rendered the principle of 'leave-no-one behind' an empty phrase. The analysis also found that national-level meta-governance structures are somewhat dysfunctional, partly due to a lack of strategy and policies on multi-stakeholder engagement. Thus, the latter's efforts and ability to monitor and demand accountability from the government are constrained by the political context and regulations enacted to side-line them. Finally, we contribute to the value of using work from government to governance (Rhodes 1997, 2007) and to meta-governance (Gjaltema et al., 2020) in accounting research, which in this instance helped trace the nature of Tanzania's national-level governance regime for adopting its SDG framework, and its underlying rationalities and contradictions.

The remainder of the paper is structured as follows: the next section explores the relationship between accountability and governance and how the two concepts have evolved and their significance in implementing the SDGs. We then situate our study within from government to governance work to analyse contemporary changes in the traditional state governance structure and employ the meta-governance work to gauge which forms of governance may best deliver the SDGs within a DC. This is followed by sections that provide contextual information on how socio-political factors in Tanzania shaped the governance regime adopted; detail the research methods employed; and present the empirical findings. The last section discusses the study's implications and reflects on avenues for future research. 


\section{Accountability and governance and the SDGs}

To understand the accountability and governance mechanisms adopted at the national level by the Tanzanian government to localise the SDGs, it is important to explore the relationship between the accountability and governance concepts and how these have evolved and been diffused in the public sector. There has been a growing interest in 'accountability' and 'governance' in practice and academia (Goddard, 2005; Woolgar and Neyland, 2013). Despite much academic debate, 'accountability' and 'governance' remain contested concepts, with no universally agreed definitions (see Messner, 2009; Meuleman, 2014). In this paper, following Meuleman (2014), governance is viewed as the totality of interactions, instruments, procedures and processes involving the government, private sector, NGOs and actors that collaborate to tackle public challenges or societal problems (p.886). Accountability is considered as 'the duty to provide an account (not necessarily a financial account) or reckoning of those actions for which one is held responsible' (Gray et al., 1996, p. 38). It is presumed to be a cornerstone of a particular mode of governing (Woolgar and Neyland, 2013).

Within the public sector, accountability and governance concepts have evolved and changed over the past four decades, consistent with paradigm shifts about its role and structure (Parker and Gould, 1999; Roberts, 1991, Messner, 2009). Accountability was historically grounded in bureaucratic centralised, hierarchical power structures, with one official reporting and being liable to a superior who could enforce sanctions for non-compliance or nonperformance of meeting formal rules and targets (Jarvis 2014). Here, governance incorporates structures that define the responsibilities of the various stakeholders within the public sector organisation, the capabilities they need to meet these responsibilities, and tools such as internal control and external accountability systems to monitor progress (Mulgan, 2000). Transparency of governance processes is often assumed to be necessary for public accountability, namely holding authoritative actors answerable for their actions and subjecting them to evaluation and redress by those affected (Roberts, 1991, Messner, 2009).

Public sector accountability became even more interesting and significant with the introduction of New Public Management (NPM) governance reforms ${ }^{4}$ in the 1990s (World Bank, 1992). These significantly changed the boundaries of the public sector, along with its financing and management techniques, governance structures, responsibilities, controls, and accounting concepts (Broadbent and Guthrie, 2008). The notion of accountability was extended beyond a 'principal-agent relationship', as public organisation actors were made accountable to both internal and external stakeholders (Almqvist et al., 2013). Accountability in this study is viewed as, 'an obligation of persons or entities entrusted with public resources to be answerable for the political, public, managerial, professional and personal responsibilities that have been conferred on them and to report to those that have conferred these responsibilities' (Boncodin (2007, p. 87). However, the implementation of NPM governing reforms has often failed to promote the desired transparency and accountability of public sector management, especially in DCs (Bakre et al., 2017) where the focus continues to be on hierarchical governance (Almqvist et al., 2013).

More porous and blurred boundaries in the public sector in the twenty-first century have brought an increasing shift towards network forms of governance (Kooiman, 2003; Rhodes, 2007), associated with a shift from 'government' to 'governance' (Rhodes, 2007). In this way, governance reflects a shifting political interest from institutional arrangements based on hierarchical command-and-control strategies (government) and from neo-liberal solutions (market) to network forms of governing (Meuleman and Niestroy, 2015). Governance here

\footnotetext{
${ }^{4}$ This includes privatisation, outsourcing, withdrawal of the state and integration of private sector management concepts and market techniques in the public sector, based on the assumption that NPM will improve the mechanisms of governance and accountability and in turn enhance public sector performance results (World Bank, 1992).
} 
goes beyond hierarchical steering by the state to include multiple 'networks' of actors (Sørensen, 2006). Accountability in this context is defined by Aucoin and Jarvis (2005) as, "parties involved [in] shared authority and responsibility ... [considered] . . . accountable to one another for the discharge of their respective responsibilities in the collective undertaking' (p.36). More collaborative forms of governing are adopted, incorporating more horizontal relations, formal and informal arrangements; processes of interaction among multistakeholders are iterative (Boven, 2007); and actors become accountable to each other for their involvement in a partnership.

While the legal and regulatory frameworks for sustainability issues such as climate change, may be established by formal institutions, it is argued that sustainability governance should incorporate interventions designed and implemented by non-state actors, including businesses, non-governmental organisations and communities (Meuleman, 2015). The participation and inclusion of different actors requires institutional structures that foster policy coherency and reflexivity; an adaptive regulatory environment and democratic institutions and regulatory systems for the actors involved being held to account (Martinez and Cooper, 2017). The governance system for implementing the SDG framework is thus complex and should integrate both state and non-state actors into national and local policy processes and combine different modes of governing (market, network and hierarchical) to promote public accountability.

\section{From government to governance}

The governing of contemporary society has been portrayed as evolving from government to governance, i.e., from being governed through the exercise of sovereign rule by hierarchically organised political institutions, to a society 'in which a multitude of public and private actors interact to govern society' (Sørensen, 2006, p. 99). This notion, when linked to meta-governance, helped us understand what governance approach may be most effective in Tanzania when localising the SDGs. Table 1 summarises the main features and different forms of governance (i.e., government, governance and meta-governance). It shows the characteristics of key governance dimensions and properties from the perspective of these different governance styles.

Table 1: From government to governance to meta-governance

\begin{tabular}{|c|c|c|c|}
\hline & Government & Governance & Meta-Governance \\
\hline Actors & $\begin{array}{l}\text { Government: } \\
\text { politicians, }\end{array}$ & $\begin{array}{l}\text { Multi-stakeholders: public, } \\
\text { private sector, non- } \\
\text { governmental organisations, } \\
\text { think tanks, \& CSOs and } \\
\text { other societal actors }\end{array}$ & $\begin{array}{l}\text { Multi-stakeholders: public, } \\
\text { private sector, non- } \\
\text { governmental organisations, } \\
\text { think tanks, \& CSOs and } \\
\text { other societal actors }\end{array}$ \\
\hline Rationality & $\begin{array}{l}\text { Sovereign rule } \\
\text { Formal procedures }\end{array}$ & $\begin{array}{l}\text { Polycentric multi-layer } \\
\text { institutions: both formal and } \\
\text { informal }\end{array}$ & $\begin{array}{l}\text { Polycentric multi-layer } \\
\text { institutions: both formal and } \\
\text { informal }\end{array}$ \\
\hline $\begin{array}{l}\text { Policy making } \\
\text { process }\end{array}$ & $\begin{array}{l}\text { State-centred (steer and } \\
\text { monitoring) }\end{array}$ & Society -centred & Society -centred \\
\hline Regulators & $\begin{array}{l}\text { State actors charged } \\
\text { with duty of governing: } \\
\text { politician and state } \\
\text { bureaucracy }\end{array}$ & $\begin{array}{l}\text { Network of actors: public, } \\
\text { private sector, non- } \\
\text { governmental organisations, } \\
\text { market, think tanks, \& CSOs } \\
\text { and other societal actors }\end{array}$ & $\begin{array}{l}\text { Meta-governors: public, } \\
\text { private sector, non- } \\
\text { governmental organisations, } \\
\text { market, think tanks, \& } \\
\text { CSOs and other societal } \\
\text { actors }\end{array}$ \\
\hline Boundaries & $\begin{array}{l}\text { Clear boundary } \\
\text { between public and } \\
\text { private }\end{array}$ & $\begin{array}{l}\text { Blurring boundaries between } \\
\text { public and private }\end{array}$ & $\begin{array}{l}\text { Blurring boundaries } \\
\text { between public and private }\end{array}$ \\
\hline
\end{tabular}




\begin{tabular}{|l|l|l|l|}
\hline Forms of governing & $\begin{array}{l}\text { Hierarchical } \\
\text { Top-down } \\
\text { regulatory control }\end{array}$ & $\begin{array}{l}\text { Non-hierarchical } \\
\text { participatory and } \\
\text { collaborative interaction } \\
\text { between state and non-state } \\
\text { actors }\end{array}$ & $\begin{array}{l}\text { Combination of } \\
\text { Hierarchical } \\
\text { + Market governing } \\
\text { + Network governing }\end{array}$ \\
\hline
\end{tabular}

In a government to governance perspective, 'government' refers to the exercise of state power based on principles such as sovereignty, territoriality and citizenship (Rosenau, 1992). Governance, by contrast, is more complex. It stems from the perceived weakness of marketisation and other neoliberal reforms, and instead advocates pluralisation of policy whereby self-organising and interorganisational networks steer and regulate society (Rhodes, 1992). It incorporates a plethora of formal and informal institutions, mechanisms and processes for formulating and implementing public policy (Johnston, 2015; Sorensen and Torfing, 2005). For example, focusing on relational aspects, governance has been defined as, '... [t] he totality of interactions, in which government, other public bodies, private sector and civil society participate, aiming at solving societal problems or creating societal opportunities' (Meuleman, 2008 p. 11). Here, the state incorporates a new and diverse assemblage of actors, including states, international organisations, non-governmental organisations (NGOs), public and private organisations and think tanks (Sørensen and Torfing, 2009). Thus, governance becomes a more encompassing phenomenon that embraces informal contributions from a network of nongovernmental actors that can supplement and supplant a government's formal authority (Rhodes, 2007). As no single actor, public or private, has sufficient knowledge or information required to solve complex dynamic and diversified problems (Kooiman, 1993), networks are considered integral for states shifting from government to governance, and formulating new means of governing society (Rhodes, 1992; Sørensen and Torfing, 2009). This resonates with calls for 'good governance' and accountability being central to the SDGs' agenda (United Nations, 2015). As Biermann et al. (2017) posited:

While the SDGs hold a great transformative potential, their collective success depends on several institutional factors, such as the extent to which states formalize their commitments, strengthen related national governance arrangements, translate the global ambitions into national contexts, integrate sectoral policies, and maintain flexibility in governance mechanisms (p. 26).

Management, public administration and organisational research have revealed an increasing interest in from government to governance shifts that: challenges traditional hierarchical modes of command-and control; espouses the need to change the role and governing capacity of the state; and recommends more multi-stakeholder interaction and involvement in governance to address governance failures and promote accountability (Johnston, 2015; Klijn, 2008; Gjaltema et al., 2020; Rhodes 1997, 2007; Bevir, 2006). This promotes new patterns of interaction between governments and society, blurs the boundaries between public and private, and seeks governing arrangements that do not rely exclusively on the authority, legitimacy and sanctions of governments (Stoker, 1998; Pierre and Peters 2000, 2005; Kooiman, 2003). Networks are deemed essential for expanding the public sphere, addressing complex public problems, cultivating inclusive policy making, managing public issues, and strengthening accountability (Bevir, 2010). To achieve this requires new systems, incorporated in legislation and regulatory frameworks that: emphasise accountability; different forms of collaboration between state and non-state actors; and empower key stakeholders to help formulate and implement public policy (Klijn, 2008; Rhodes, 2007).

'Government' and 'governance' form two poles on a continuum, namely from the state employing traditional hierarchical governing through authoritative nationally organised political institutions (government), to governing through a multitude of public and private actors from different policy levels (governance) (Rhodes 1997, 2007). The latter replaces the 
traditional idea of a sovereign state governing society top-down through comprehensive planning, programmed action and detailed regulations from hierarchically organised political institutions, with polycentric governance based on interdependence, negotiation, and trust (Sørensen \& Torfing, 2007). It is anticipated that relationships will be characterised by networks that are based on resource interdependency and trust (Rhodes, 2007); governments would become the centre of a network of interactions, interdependence and cooperation among varied actors; and the emphasis in governance processes is on participation, equitable power relations, trust, fairness and inclusion (Sørensen \& Torfing, 2007).

In many DCs, however, where boundary and social relations between government and governance remain unclear, such collaborations may be problematic (Bayart, 2009; Lauwo et al., 2016). Arguably, the weak institutionalisation of political practices and their structures of power in DCs, shape their socio-political and economic reality and their governance and accountability systems differently to developed countries (Bayart, 2009). For example, despite the pivotal roles NGOs and CSOs play within global governance, their capacity to campaign about public policies, associated socio-economic problems and better accountability from governments in many DCs, are constrained by their reliance on external funding, mostly from Western donors or governments pursuing a self-interested agenda (Lauwo et al., 2016). Unless an integrated holistic governance approach, coupled with multi-stakeholder engagement and collaboration between the government, the private sector, NGOs, and other CSOs, is adopted, attaining the SDGs in DCs may remain a dream (Jessop, 2011).

\subsection{The governance of governance: meta-governance and the SDGs}

Scholars argue that the complexity of and interrelations between the SDGs require an integrated and holistic approach to decision-making, implementation and monitoring by public and private sector, and civil society actors (Boas et al. 2016; Meuleman and Niestroy, 2015). Hence, we turned to scholarship on meta-governance, which is commended as essential for enhancing accountability and transparency in governance. Meta-governance involves the state working in collaboration with multiple non-state actors from the private sector, NGOs and CSOs who therefore play a greater role in governance (Christopoulos et al. 2012, p.311). The framework is premised on the belief that coordination between one or more governance modes (hierarchy, networks and market based) can help overcome governance failures in addressing complex societal problems (Jessop, 2011, p.106; Torfing and Triantafillou, 2011). From a meta-governance perspective, the governance of successful SDGs requires the active involvement of actors beyond state-actors alone, premised on the belief that private sector, NGOs, and other non-state actors should play a greater role in governance systems (Christopoulos et al. 2012, p.311).

Public policy scholars have defined meta-governance broadly to incorporate how the scope and scale of governance is actually expanding beyond the traditional state-centred topdown hierarchical form of governance, by forging new governance partnerships with a range of social actors (Heritier and Rhodes 2011; Sørensen and Torfing, 2007). As Meuleman (2008) stressed, 'meta-governance is a means by which a degree of coordinated governance can be achieved, by designing and managing sound combinations of hierarchical, market-based and network governance, to achieve the best possible outcomes ...' (Meuleman (2008 p. 68). Thus, what is being proposed goes beyond the from government to governance debate to the governance of governance and 'the totality of interactions of governments, other public bodies, private sector and civil society, aimed at solving societal problems or creating societal opportunities' (Meuleman, 2008, p.11).

In contrast to other governance models (hierarchy, networks or market-based), metagovernance incorporates a broader range of factors (institutional, environmental, social, and contextual) and local concerns, and combines different governance styles to protect the public 
interest, and to safeguard accountable, transparent and representative governance (Meuleman, 2008; Gjaltema et al., 2020). As each individual governance style has its own strengths and weaknesses ${ }^{5}$, the meta-governance approach recommends a combination of different governance styles (Meuleman, 2008). Within this approach, governing becomes a shared responsibility of state, market and civil society (Kooiman, 2003; Pierre \& Peters, 2000; Rhodes, 1997; Stoker, 1998) and needs new forms of governance because "problems have emerged that cannot be managed or resolved readily, if at all, through top-down state planning or marketmediated anarchy" (Jessop, 2003, p. 10) ${ }^{6}$.

Thus, while the meta-governance literature acknowledges the importance of both government and governance, it does not focus only on government steering society or society being a sphere of self-governing networks (Gjaltema et al., 2020). Instead, it acknowledges the importance of different forms of governance in addressing societal issues, such as SDGs. However, combining different forms of governance when localising SDG implementations requires the state to play a strong role in creating multi-sector, multi-level and multistakeholder collaboration and engagement, and improving accountability and transparency (Meuleman, 2008).

This may be problematic in DCs such as Tanzania, where decision making is concentrated in top-down hierarchical structures, and the involvement of non-state actors (such as NGOs and other pressure groups) and regulatory enforcement remains weak (Lauwo et al., 2016). Arguably, poor multi-stakeholder engagement and collaboration in DCs can constrain their efforts towards achieving the SDGs (see Jessop, 2011). Thus, unless an integrated holistic governance approach is adopted, coupled with multi-stakeholder engagement and collaboration between the government, the private sector, NGOs, and other CSOs, attaining the SDGs in DCs will remain a dream. As we shall demonstrate in section 4, the Tanzanian government has not created the means for promoting multi-stakeholder engagement and collaboration, whether formal or informal. Hence, the potential claimed for meta-governance may be difficult to realise.

\section{Governance in Tanzania}

It is not possible to understand the national governance system that supports the localisation of SDGs in Tanzania without discussing governance reforms over the past three decades and the regulatory environment and how these have shaped interactions between state and non-state actors (Harrison \& Mulley, 2008). Traditionally, the governance structure has had a clear hierarchy and top-down structure, emanating from the central government down to local district and village levels (URT, 2018). In the early 1990s, like many DCs, Tanzania adopted structural adjustment programmes (SAPs) requiring reforms that decentralized its administrative structure to promote inclusive participation, fair competition, governance, and accountability for the management of public resources (World Bank, 1989). The subsequent introduction of public sector management reforms, deregulation, and privatisation from the mid-1990s radically changed Tanzania's government and governance structures (Harrison, 2008). The reforms increased private sector participation in the economy and introduced new codes relating to transparency and good governance (Lauwo et al., 2016). Concurrently,

\footnotetext{
${ }^{5}$ For example, in a centralised top-down hierarchical context (such as in DCs), accountability and transparency may be considered as a threat, as it may lead to governance failures, while in a network context, it may be difficult to single out who is to be held accountable for governance failures and how to hold actors into account for outcomes that are a result of collaboration of various actors collaborating in opaque processes (Klein and Koppenjan, 2014). In a market-based approach, accountability mechanisms may risk focusing too much on competition, profitability, and other market criteria (Meuleman and Niestroy, 2015).

${ }^{6}$ For example, network governance focuses on self-organising coordination of network on multi-stakeholders: public, private, CSOs, and other societal actors (Klijn 2008; Klijn and Koppenjan, 2016; Sørensen and Torfing 2009), while market-oriented governance creating conditions to promote competition, and efficiency in managing public resources (Meuleman and Niestroy, 2015).
} 
Tanzania implemented a plethora of legislations including the Anti-Money Laundering Act No. 12 2006; the Prevention and Combating of Corruption Act, 2007; and the National Prosecution Service Act 2008, No.27, intended to promote good governance and sustainable growth (URT, 2018). In addition, the profile of local NGOs increased (Abrahamsen, 2001; Financial Times, 2001); for example, according to the government's official records there were 2004 NGOs in 2000, compared to just over 800 in 1995 (Business Times, 2001ab).

However, despite the high expectations that these reforms would promote good governance, improve accountability and deliver mass prosperity, significant barriers to formal and informal accountability and horizontal governance in Tanzania remained (Chachage, 2003; Todd and Mamdani, 2017; Human Rights Watch, 2019; UNDP, 2016). They included weak institutions and regulations and insufficient capacity for local actors to demand more accountability and good governance (Kelsall, 2003). Consequently, despite the claims and optimism that these reforms would promote good governance, deliver mass prosperity and support the realisation of SDGs, Tanzania remains one of the poorest African countries (United Nations, 2018). In 2016, it was ranked at 152 amongst 188 countries worldwide, with $46.6 \%$ of its population living below the income poverty line and $32.1 \%$ suffering from severe multidimensional poverty (UNDP, 2016, p. 204). A more recent World Bank poverty assessment report noted that despite sustained economic growth and a persistent decline in poverty, the absolute number of poor people grew from 13 million in 2007 to 14 million (World Bank, 2019). Amongst the reasons cited for these disappointing results include the absence of adequate regulatory frameworks and insufficient interaction between the government and nonstate sectors (Lauwo et al., 2016; Human Right Watch, 2019). Moreover, despite the NGOs' pivotal role in promoting good governance by voicing the concerns of the poor and marginalised, and holding the government to account, local NGOs remained understaffed, underfunded and/or heavily donor dependent (Kelsall, 2002; Lauwo et al., 2016). Hence, it is questionable how far the regulatory framework and NGO activism within Tanzania can promote the accountability and governance required to achieve the SDGs.

Further changes in governance structures in 2015 have had serious implications on the governance of SDGs. When John Pombe Magufuli was elected as the fifth President, he adopted a nationalistic approach to economic policy. He prioritized efforts to clampdown on systemic corruption and to improve good governance and accountability for the management of public resources (URT, 2018). His abrasive approach to the management of state affairs was praised by many in Africa, but his authoritarian regime was also criticised after his sudden death in March 2021 (Human Rights Watch, 2019). For example, under Magufuli, Tanzania adopted the Statistics Act, 2015 (amended in 2018), which provided regulations on what types of information could be disclosed and required outside agencies (including research institutions, news outlets, or NGOs) to receive permission before publishing official statistics (Amnesty International, 2019). The Cybercrimes Act, 2015 was also criticised for extending police power across various domains, including elections, NGOs and opposition parties, thereby infringing freedom of expression (Human Rights Watch, 2019). In 2017, a re-vetting of the legal status and activity of existing NGOs and similar entities sought to regulate and control NGOs and other CSOs (Human Rights Watch, 2019). This required local officials to certify their good standing, and temporarily halted the registration of new ones. The NGO Regulations, 2018 required NGOs to publicly declare their sources of funds, expenditures and intended activities, or face deregistration (Human Rights Watch, 2019). These regulations reduced the number of NGOs and other CSOs, and constrained their ability to voice marginalised issues, and demand accountability from government ${ }^{7}$. Thus, although NGOs have

\footnotetext{
${ }^{7}$ https://www.civicus.org/index.php/media-resources/media-releases/open-letters/3163-civil-society-groupsexpress-concern-over-worrying-human-rights-decline-in-tanzania.
} 
emerged as distinct actors within the international political economy and are expected to be meta-governors supporting the implementation of the SDGs (Meuleman, 2018), their capacity to do so in Tanzania has been limited.

While governments are expected to establish rules for network governance (Sorensen and Torfing, 2007), in Tanzania, governance still represents sovereign rule by the state, within top-down hierarchical government structures, with limited involvement of NGOs and CSOs (Harrison, 2008). Incentives to transfer control downwards are weak as the governance structure centralises political power and hierarchical decision making and resource allocation (Human Rights Watch, 2019). Thus, the government's dominance, combined with a lack of representation of grassroots actors coupled with their inability to participate in decision making and demand accountability, has reinforced Tanzania's hierarchical governance. This suggests that implementing the envisioned meta-governance that would combine different governing styles (hierarchy, market, and network), to support the localisation of the SDGs in Tanzania, may prove problematic.

Hence our research sought to analyse how the SDGs have been localised in Tanzania; the level of multi-stakeholder engagement and the challenges it has encountered; how governance at the national level has underpinned accountability at the local level; and how, if it at all, this has incorporated shifts from government to governance to meta governance.

\section{Research methods}

A qualitative approach was adopted to garner a rich understanding of the governance and accountability mechanisms supporting the implementation of the SDGs in Tanzania. The empirical core of the study is a series of one-to-one interviews and focus group discussions conducted by a researcher between May to July in 2018 in Tanzania. Data was also collected from relevant laws and regulations, government policy documents, circulars and reports, Voluntary National Reports (VNRs) and NGO reports.

Eight one-to-one interviews were conducted at the interviewees' places of work (see Table 2 for details of interviewees). The primary and initial motivation for selecting interviewees was their role and involvement in preparing Tanzania to engage with the design, signing into policy, and ultimately the adoption of the UN's 2030 Agenda. They included central government officials in key departments and ministries responsible for implementing the SDGs' framework, representatives from NGOs/CSOs, the private sector, think tanks, academics and the United Nations office in Tanzania.

Representatives from the United Nations office in Tanzania, CSOs and central government officials participated in three focus group interviews to gauge their perspectives of and involvement in localising the SDGs. Purposeful sampling was used to select respondents with a deep understanding of the SDGs or were involved in the localisation process. The interviews and focus group discussions provided insights into the Tanzanian government's approach to adopting the SDGs' agenda and its localisation, and the nature of governance and accountability at the national level supporting this. The interviews also explored the involvement of non-state actors and the challenges they encountered, which we believe is critical given the growing recognition that the state and its bureaucratic structures alone cannot be relied upon to attain the SDGs and the principle of "leave-no-behind" they embody. An interview guide was designed to enable interviewees to participate in a loosely guided (openended) conversation to facilitate the emergence of new themes (of critical relevance to the interviewee) (O'Dwyer et al., 2005). The one-to-one and focus group interviews lasted from 45 to 90 minutes and were digitally recorded. Where recording was not permitted, notes were taken during the interviews.

Table 2. Summary of the interviewees 


\begin{tabular}{|c|c|c|c|}
\hline \multirow{2}{*}{ Research Site } & \multicolumn{2}{|l|}{ Interviewee } & \multirow{2}{*}{ Number } \\
\hline & Category & Code & \\
\hline \multicolumn{4}{|l|}{ Focus group: } \\
\hline $\begin{array}{l}\text { 1. MoFP }- \text { Poverty } \\
\text { Eradication Division }\end{array}$ & Government official & MoFP-PED: Representatives 1, 2 and 3 & 3 \\
\hline $\begin{array}{l}\text { 2. African Philanthropic } \\
\text { Foundation }\end{array}$ & $\mathrm{CSOs} / \mathrm{NGOs}$ & CSO: Representatives 1 and 2 & 2 \\
\hline 3. UN Tanzania Office & Development partner & DP: Representatives 1,2 and 3 & 3 \\
\hline \multicolumn{4}{|l|}{ One-to-one: } \\
\hline $\begin{array}{ll}\text { 1. } & \text { MoFP }- \text { Poverty } \\
\text { Eradication Division }\end{array}$ & Government official & MoFP-PED: Representative 4 & 1 \\
\hline $\begin{array}{l}\text { 2. President's Office } \\
\text { Planning Commission }\end{array}$ & Government official & POPC Representative & 1 \\
\hline $\begin{array}{l}\text { N. National Bureau of } \\
\text { Statistics }\end{array}$ & Government official & NBS Representative & 1 \\
\hline $\begin{array}{l}\text { Economic and Social } \\
\text { Research Foundation }\end{array}$ & Think tank & ESRF Representative & 1 \\
\hline $\begin{array}{l}\text { Tanzania Private } \\
\text { Sector Foundation }\end{array}$ & Private sector & TPSF Representative & 1 \\
\hline 6. Researchers & Academic & Academics 1 and 2 & 2 \\
\hline 7. UN Tanzania Office & Development partner & DP: Representative 4 & 1 \\
\hline Total & 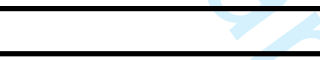 & & 16 \\
\hline
\end{tabular}

Negotiating and getting access to key stakeholders, particularly government officials, was problematic due to the government's increased surveillance of the media, NGOs and political opposition. This surveillance, whose purpose is supposedly to protect so-called sensitive information, has created a culture of fear and secrecy in most government departments/units ${ }^{8}$. As mentioned in section 4 above, this atmosphere has been created through a succession of repressive legislations. Whilst negotiating access prior to visiting Tanzania, several government officials agreed to be interviewed but for reasons unknown to the authors, became unavailable during fieldwork. Consequently, we could interview only 16 participants. Nevertheless, they provided rich insights on the main issues/empirical questions in our original interview protocol and those that evolved during fieldwork.

To supplement the fieldwork data, various archival records were used (see Table 3). We collected, reviewed, and analysed information from UN, UNDP and UNRISD reports, audit reports by the National Audit Office of Tanzania (NAOT), various Tanzania government reports and websites, reports by think tanks, and newspaper clips and blogs which provided documentary evidence on the implementation of SDGs in Tanzania.

\footnotetext{
${ }^{8}$ https://www.hrw.org/report/2019/10/28/long-i-am-quiet-i-am-safe/threats-independent-media-and-civilsociety-tanzania.
} 
Table 3. Summary of the documents analysed

\begin{tabular}{|c|c|c|}
\hline & Source and Type of Document & Publication Year \\
\hline $\boldsymbol{A}$ & Tanzania' government reports & \\
\hline 1 & $\begin{array}{l}\text { Voluntary National Review (VNR) 2019: A Report on the Progress of the SDGs } \\
\text { Implementation in the URT } \\
\text { (https://sustainabledevelopment.un.org/memberstates/tanzania) }\end{array}$ & 2019 \\
\hline 2 & $\begin{array}{l}\text { National Five-Year Development Plan II (FYDP II): 2016/17 - 2020/21: } \\
\text { Nurturing Industrialization for Economic Transformation and Human } \\
\text { Development } \\
\text { (https://mof.go.tz/mofdocs/msemaji/Five\%202016 17 2020_21.pdf) }\end{array}$ & June 2016 \\
\hline 3 & $\begin{array}{l}\text { Performance Audit on Preparedness for Implementation of Sustainable } \\
\text { Development Goals: A Report of the Controller and Auditor General - March } \\
2018 \text { (http://www.nao.go.tz/?wpfb dl=261) }\end{array}$ & March 2018 \\
\hline 4 & NBS report & 2019 \\
\hline $\boldsymbol{B}$ & United Nations reports & \\
\hline 1 & $\begin{array}{l}\text { World Economic Situation and Prospects } 2018 \text { Report } \\
\text { (https://www.un.org/development/desa/dpad/wp- } \\
\text { content/uploads/sites/45/publication/WESP2018_Full_Web-1.pdf) }\end{array}$ & 2018 \\
\hline 2 & $\begin{array}{l}\text { Transforming our world: the } 2030 \text { Agenda for Sustainable Development - } \\
\text { A/RES/70/1: Resolution adopted by the UN General Assembly } \\
\text { (https://sustainabledevelopment.un.org/post2015/transformingourworld) }\end{array}$ & September 2015 \\
\hline 3 & $\begin{array}{l}\text { The future we want - outcome document of the RIO+20 UN Conference on } \\
\text { Sustainable Development. Rio de Janeiro, Brazil } \\
\text { (https://sustainabledevelopment.un.org/content/documents/733FutureWeWant.pdf }\end{array}$ & June 2012 \\
\hline$C$ & NGOs and CSOs reports & \\
\hline 1 & $\begin{array}{l}\text { Tanzania Civil Society Report on the Sustainable Development Goals } \\
\text { (http://www.una.or.tz/resources/) }\end{array}$ & 2019 \\
\hline 2 & $\begin{array}{l}\text { Good News Blog (December 14, 2018): Parliamentary Group on Sustainable } \\
\text { Development launched in Tanzania (https://www.ykliitto.fi/uutiset-media/yk- } \\
\text { blogi/good-news-blog-parliamentary-group-on-sustainable-development- } \\
\text { launched-in) }\end{array}$ & December 2018 \\
\hline 3 & $\begin{array}{l}\text { Blog post by ESRF, Tanzania (June 6, 2016): Implementation of SDGs in } \\
\text { Tanzania: The Way Forward (http://southernvoice.org/implementation-of-sdgs- } \\
\text { in-tanzania-the-way-forward/). }\end{array}$ & June 2016 \\
\hline $\bar{D}$ & Newspapers and Other News Media & \\
\hline 1 & $\begin{array}{l}\text { SABC News }- \text { "Africa at risk of not achieving UN sustainable development goals } \\
\text { 2030" (https://www.youtube.com/watch?v=5BjjlDq8evI) }\end{array}$ & \\
\hline 2 & Tanzania Affairs Magazine (http://www.tzaffairs.org/scanned-pdf-issues/) & Various issues \\
\hline 3 & Afrobarometer (http://www.afrobarometer.org/) & \\
\hline 4 & The Guardian, This Day, Tanzania Daima, Mwananchi, Daily News, The Citizen & \\
\hline
\end{tabular}

A thematic analysis was adopted to generate themes that were relevant to our research objectives and theoretical perspective (Miles and Huberman, 1994). The theoretical insights discussed in section 2 helped structure the analysis of the empirical evidence and construct a theoretically informed analysis. We adopted an iterative approach of analysis between the data and emergent themes on the one hand and the prior literature and theory on the other (Arora and Lodhia, 2017). Each interview transcript and archival material was screened for themes related to the key elements in the shift from government to governance and meta-governance 
framework (see Table 1). Initially, the processes, structures, and arrangements supporting the localisation of the SDGs were analysed. This allowed the researchers to analyse interactions between state and non-state actors to ascertain: the extent of multi-stakeholder engagement; the existing governance and accountability structures supporting the localisation of the SDGs; and the challenges encountered in coordinating and steering meta-governance within a topdown hierarchical environment. Each researcher carried out thematic mappings, then compared notes, and discussed and resolved the minor discrepancies that arose (Arora and Lodhia, 2017). Critical reflection on the research process, especially why certain themes emerged rather than others, and the complex interpersonal dynamics involved, offered further insights.

\section{Findings and analysis}

In September 2015, the Tanzania government - like many other countries- endorsed the UN Agenda 2030 and the SDGs and launched several ambitious initiatives to strengthen national-level implementation. The endorsement of the SDGs framework by the Tanzanian government also coincided with the presidential election in October 2015 that brought John Magufuli to power as the fifth President of Tanzania. He changed the cabinet and introduced major fiscal and regulatory changes, which had significant implications for the governance structure that was enacted to support the localisation of the SDGs framework (URT, 2018). The endorsement also occurred when the government was reviewing its medium-term plans namely, the National Strategy for Growth and Reduction of Poverty II (NSGRP II, 2010/112014/15), and the first phase of the National Five-Year Development Plan (FYDP I, 2011/122015/16). Following the FYDPII priorities, Tanzania prioritised the implementation of nine out of the seventeen SDGs: No poverty (Goal 1); Zero Hunger (Goal 2); Good Health and Wellbeing (Goal 3); Quality Education (Goal 4); Gender Equality (Goal 5); Clean Water and Sanitation (Goal 6): Affordable Clean Energy (Goal 7); Industry, Innovation and Infrastructure (Goal 9); and Partnerships for the Goals (Goal 17) (URT, 2016, NAOT, 2018). The next section shows how the SDGs framework has been localised through national policies and highlights the institutional arrangements at the local level for supporting its implementations in Tanzania.

\subsection{Localisation of the SDGs: Governance and accountability structure at the national level}

The state and its agencies provide the ideological, legal and institutional structure for supporting multi-stakeholder partnership and different forms of governance (Batley, 2006). In Tanzania, the Ministry of Finance and Planning (MoFP), supported by the President's Office Planning Commission (POPC), was initially mandated to coordinate the implementation and localisation of the SDGs into the national plans. The POPC was responsible for providing overall oversight of the SDGs framework implementation process while the MoFP (URT, 2019) was responsible for coordinating and monitoring the localisation of the SDGs. The MoFP was responsible for: mainstreaming SDG indicators; collecting data for monitoring SDG implementation at the national level; and reporting on implementation progress at the HighLevel Political Forum - HLPF (URT, 2019b). In June 2019, the MoFP delegated the SDGs reporting responsibility to the Poverty Eradication Department (PEDP), an independent unit under the MoFP responsible for poverty issues, which includes SDGs (URT, 2019). The PEDP produced an SDG-baseline report, an SDG-progress report (Ministry of Finance and Planning, 2017) and the first Voluntary National Review (VNR) for the 2019, submitted to the UN HighLevel Political Forum in New York (URT, 2019b). For example, the VNR report (2019) stated that 'Tanzania is doing reasonably well in goals 2, 3, 4, 5, 6, 8, 10, 16' (p.xvi). According to the report, 'goals 7, 9,11, 12 are likely to be achieved with stepped-up efforts; while goals 1, 13, 14, 1517 will need significant local efforts and international support to achieve' (p.xvi). 
The National Bureau of Statistics (NBS) collects and coordinates official statistics, tracking progress against the SDGs' indicators at the national and local level (URT, 2019b). Sectoral ministries and departments have overall responsibility for and oversight on National Development Plans and policies and provide the practical tools to monitor the implementation of the SDGs, which are then fed into their reviews on their achievement in their thematic areas of responsibility. To ensure accountability, transparency and inclusion, the government of Tanzania established a Parliamentary Group on Sustainable Development (PGSD), responsible for monitoring the implementation of the SDGs (UNDP, 2017, 2019). According to the UNDP (2017), the purpose of the PGSD is to strengthen Parliament's role in planning, resource allocation and oversight, while reviewing the progress towards sustainable development outcomes. At the local level, some local governments have started embedding and mainstreaming the SDGs in their plans and strategies (URT, 2019). Figure 1 below shows the unique structure of the coordination and governing of SDG implementation.

Figure 1: Governing the SDGs in Tanzania

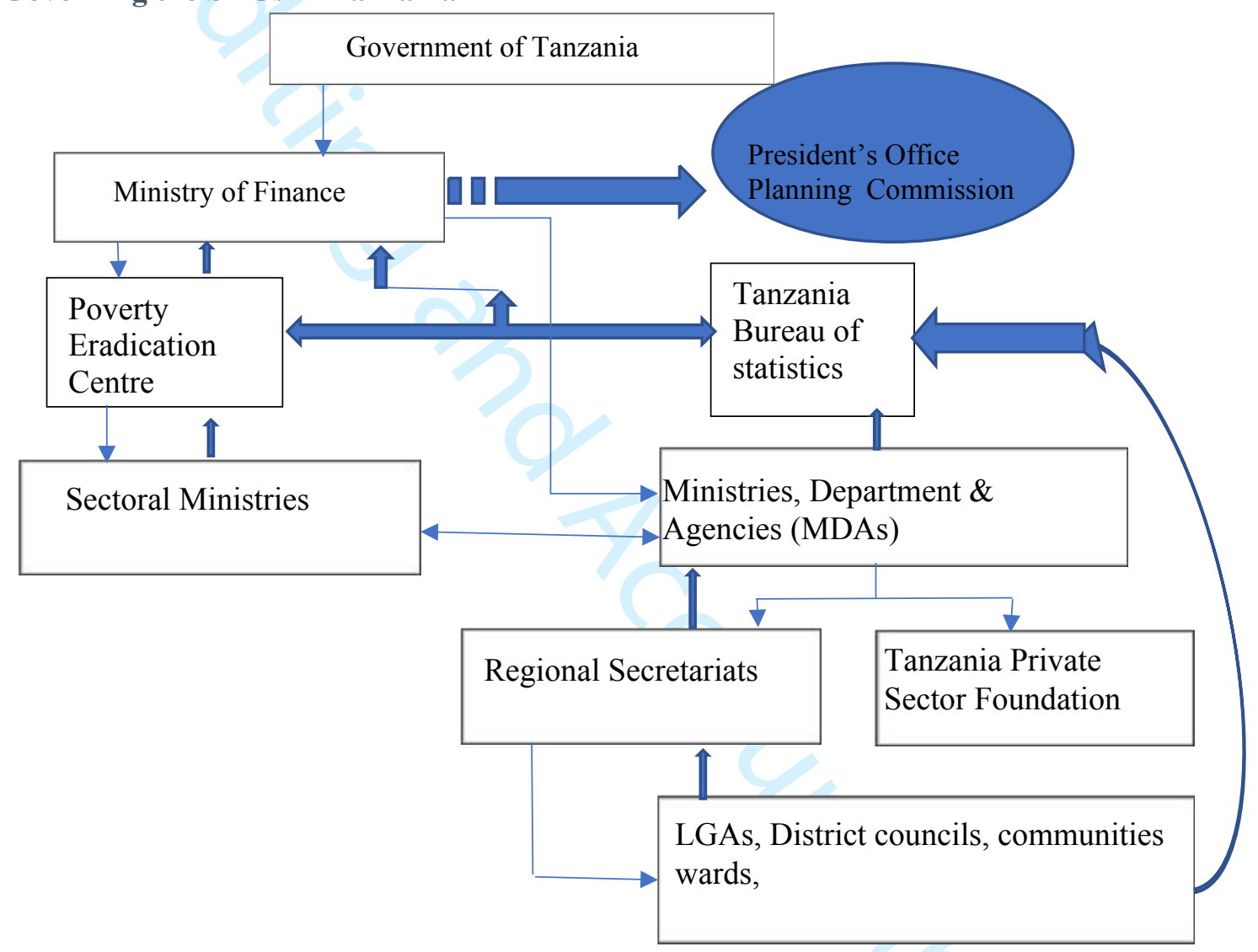

Source: Modified from Mashindano and Baregu (2016)

Coordination/Monitoring \& Reporting

Implementation

Figure 1 reflects how the localisation process of SDGs has followed existing national policies and formal institutional arrangements rather than the innovative approach required by UN resolution 70/1 (United Nations, 2015; Jonsson and Bexell, 2020). The diagram depicts both vertical and horizontal accountability systems where, for example, the Sectoral Ministers account for the SDGs targets to the Finance Ministry. These procedures are also replicated at the horizontal level of public accountability at the local level, whereby LGAs and District Councils account to their respective Regional Secretariats. This also applies at the lower tiers of representative government, in which elected representatives and the officers who work for 
them, are accountable to local citizens. In this way, institutional arrangements for localising the SDGs remain structured within the existing hierarchical top-down governing regime in Tanzania, with no specific SDG related strategy or policy being devised or enacted for engaging the key stakeholders. Instead of creating a specific policy or strategy for localisation, the process is embedded within existing governance structures and focusses on the pressing local priorities stipulated in its five-year development plan, i.e., poverty, education, healthcare, clean water, infrastructure and gender equality (VNR report, 2019, NAOT, 2018). One of the respondents explained how this was done:

". . . the government focus is based on the priority issues identified in the development plan, including addressing the endemic poverty levels, education and health care issues rather than specific SDGs. Responsible ministries are expected to focus on pressing issues identified in the national development plan, with the assumption that the SDG framework will be embedded in it. At the moment, the government interest is to address the socio-economic agenda set in its five years developmental plan" (ESRF Representative).

Government officials interviewed revealed how localisation of the SDGs remains a policy ambition, as there are no formal accountability mechanisms to enable CSOs, NGOs and other actors to scrutinise this process and demand accountability from the government and its agencies. A government official stated how, 'knowledge of the SDGs is still limited beyond those directly involved in policymaking. . . although the government has taken some initiatives to localise the SDGs, no clear policies in terms of SDGs implementation, coordination, reporting, and accountability exist' (POPC Representative). Similarly, the SDGs performance audit report reported that the MoFP had not developed a national strategy for the implementation and attainment of specific SDGs and targets (NAOT, 2018 p.ix), unlike many of its peers on the continent (e.g. Ghana, Egypt, Nigeria). The SDGs performance audit report states:

The implementation of the SDGs in Tanzania is governed by various sector policies and legislations. There is neither comprehensive legislation nor specific policy to guide the implementation and coordination of the localisation of SDGs. The implementation is done through their pre-existed sectoral policies and regulation (NAOT, 2018 p.7).

In this way, the boundary between national plans and specific SDG-reporting have remained blurred, which has had accountability implications. A think tank representative explained 'we have been keen to align the SDGs in our existing national development policy agenda. However, more is needed in terms of policy implementation, coordination and reporting' (ESRF Representative). Some respondents alluded to a rationale for linking the implementation of SDGs to the national development plan:

"We focus on mapping our strategies and mainstreaming through integrating the SDG in national and sub-national development plans and budgeting frameworks ...identifying priority areas to accelerate progress and maximise impact and policy support through pooling together the skills, knowledge and experience of respective UN agencies to support policy formulation and implementation" (DP: Representative 2).

A senior government representative commented:

"...we wanted to implement the SDG framework, but we found ourselves with another task of first preparing the five-year development plans. Then, before that, there was another strategy called 'the National Strategy for Growth and Reduction of Poverty (NSGRP)'. Now, this strategy was running independently. So we said, the NSGRP objective is to improve people's economic conditions. The objective of a development 
plan is to grow the economy, and if possible, bring some positive impact on people's lives. Therefore, we decided to integrate NSGRP, the development of human resources, and the SDG framework. . . We have decided to combine these; that is, when we are implementing our development plan, we should simultaneously be looking on other things ..." (POPC Representative).

Thus, the government's strategy for localising the SDG framework was to integrate it within the second phase of its five-year development plans (FYDP II) 2016/2017- 2020/2021 (Mashindano and Baregu, 2016; UN, 2018; URT, 2016). ${ }^{9}$ Tanzania has continued to focus on pressing socio-economic issues prominent in the national development plan, including endemic poverty levels. This was deemed essential for reconciling the UN 2030 agenda with local circumstances and providing the means to monitor the progress of implementing the SDGs framework (URT, 2019b). In so doing, Tanzania has inevitably neglected some important SDGs, e.g., goal 8, Decent work and economic growth; goal 10, Reduce inequalities within and amongst countries; goal 13, Climate Action; goal 14, Life below water; and goal 15 Life on land, which are not deemed to be priorities in Tanzania (VNR report, 2019; NAOT, 2018). Although Tanzania has embraced 9 of the 17 SDGs, and 165 of the 230 SDGs indicators, in the Second Five Years Development Plan (FYDP II) 2015/2016 to 2020/2021, it did not specify the strategy for the eight goals omitted (NAOT, 2018, p.viii). As Gupta and Nilsson (2017) have stressed, translating global aspirations into national policies requires significant administrative capacities and skills at the national level, including functioning governance systems. In turn, this requires various forms of self-regulation, multi-stakeholder engagement, and a meta-governance approach (Sørensen, 2006). The next section examines how this was done in Tanzania.

\subsection{Multi-stakeholder engagement and governance at the national level}

Governments play a major role in establishing a platform for meta-governance, its ground rules, and the regulatory order whereby governance partners can pursue their aims (Jessop, 2003). The Tanzanian government claims to have adopted a 'Whole of Society' approach to implementing the SDG framework. In so doing, it has purportedly incorporated multi-stakeholder participation and collaborative governing involving local government associations (LGAs), Parliament, the private sector, CSOs, NGOs, academic institutions, think tanks, and international organisations (Maeda and Chacha, 2019; URT, 2019b). A government official explained how collaboration between the government and key stakeholders informed this consultation process and was:

"coordinated by the planning commission section of the government with the involvement of various stakeholders including CSOs, youth, women, the private sector. This coalition identified a number of priorities. From this consultation, we came up with 10 priorities that we included as our input into the document presented at UN meetings for SDG framework formulation" (MoFP-PED: Representative 1).

In an effort to engage a wide range of stakeholders, the government claimed to have developed a roadmap specifying how stakeholder engagement, awareness creation, resource mobilisation, capacity building, domestication and localisation should be accomplished (URT, 2019b). Its first Voluntary National Review (VNR) report to the HLPF on Tanzania's nationallevel implementation of the SDGs and the UN agenda 2030, emphasised the importance of multi-stakeholder engagement and network governance:

Several stakeholders' consultations on the SDG framework implementation were conducted country-wide and involved representatives from the private sector/businesses,

\footnotetext{
${ }^{9}$ https://una.or.tz/how-are-the-sustainable-development-goals-implemented-in-tanzania/
} 
Non-Governmental Organizations (NGOs), CSOs, Development Partners, ethnic groups, academia, professional groups, labour associations, women networks and youth networks as well as the media (VNR report, 2019, p.6).

The Tanzanian government also underlined how it has used seminars, conferences and workshops to bring together key stakeholders and facilitate dialogue on strategies for localising SDGs. The VNR report (2019) stressed:

... presentations were also made at a National Planners' Conference .... a forum attended by Directors of Policy and Planning (DPPs) from Government Ministries, Independent Departments and Agencies (MDAs); Planning Officers from Regional Secretariats (RSs) and Local Government Authorities (LGAs) .. . The Government also conducted awareness and sensitisation workshops on SDGs for RSs and LGAs in order to empower and capacitate them to mainstream and incorporate national plans and SDGs into their plans and budgets (ibid., p.5).

In addition, the Tanzanian government developed an interim Sustainable Development Data Roadmap to monitor implementation of the SDG framework and to improve and better utilise sustainable development data (URT, 2019b). It also offered:

A data visualization and dissemination portal ... to facilitate the dissemination of the Goals. Stakeholder involvement and contribution towards the implementation of the SDGs is coordinated by different stakeholder apex bodies and platforms (VNR, 2019, p.ii).

The initiatives suggested in the above statements called for multi-stakeholder collaboration and adapting strategies to local contexts and needs. They also spelt out how stakeholder engagement, awareness creation, resource mobilization, capacity building, domestication and localization would be accomplished (VNR report, 2019, p. xiv). The statements suggest that the Tanzanian government has established structures to promote empowered participation and sustained interactions between key stakeholders to exchange their knowledge and ideas, consistent with the UN 2030 proposed meta-governance framework for implementing SDGs (Meuleman, 2008, 2015). Multi-stakeholder partnership is crucial for network governance in the hierarchy-network-market forms of governing (Jessop, 2003). So, we see an early analogy with the shift from government to governance (Rhodes, 1997) to meta-governance (Gjaltema et al., 2020). The pledge to leave no one behind, enshrined in its 'Whole of Society' approach, recognises that the collaboration and engagement should be open and inclusive, providing all stakeholders and groups with opportunities to participate (Kooiman, 2003). However, contrary to the government claim of multi-stakeholder consultations and engagement, the interviews with various stakeholders (presented in the next section) suggested that multi-stakeholder engagement has been limited and selective. Contrary to recommendations, there has been a lack of transparency; information on engagement processes and plans have not been clear, nor communicated to all stakeholders or published in a timely fashion and be publicly accessible (Meuleman, 2008). The SDGs performance audit report highlighted:

The SDGs localisation process was undertaken within formal top-down structures of the government with limited space for engaging civil society organisations and other local actors; Tanzania's government often worked independently and only involved other stakeholders at the final stage of the policy implementation; multi-stakeholder partnerships have not been institutionalised and its practices have been inconsistent; and currently there were no platforms created for engaging key stakeholders (as metagovernors) or specific regulations enacted to support network or market-based governance (NAOT, 2018). 
Thus, despite the emphasis on multi-stakeholder engagement at the national level, it was not clear how empowered participation and multi-stakeholder collaboration occurred in Tanzania, which is worrisome given Jessop's (2003) argument that governance without a carefully crafted policy for engaging key stakeholders may be useless. Therefore, on the one hand, the Tanzanian government, like many other countries, appeared to have established structures for promoting multi-stakeholder engagement, consistent with the meta-governance framework. On the other hand, the partnerships allegedly occur in centralised hierarchical state structures granting little space to the private sector and other non-state actors to participate and collaborate. For example, one CSOs representative interviewed stated that, "no platforms for engaging many key stakeholders (as meta-governors) or formal regulations enacted at the national level to promote informal accountability to support the implementation of the SDGs have been created '(CSO: representative 1). Moreover, the supposedly collaborative governance formulated by the government defines key stakeholders narrowly, drawing from existing top-down hierarchical-based networks. The involvement of other key stakeholders, including civil society, local NGOs, private sector networks, epistemic communities, trade unions, youth, and historically marginalized groups in the localisation of the SDGs has been very limited (NAOT, 2018). For example, looking at SDG 6, Clean Water and Sanitisation, an SDG that Tanzania is reported to be achieving reasonably well (VNR report, 2019 p. xvi), despite accountability appearing to occur in multiple-level governance structures, the government's own reports ${ }^{10}$ indicate that it still largely operates within the hierarchical structure of the government:

The Ministry of Water (MOW) is responsible for delivering clean water and sanitation services at the national level. The governance of this service does involve actors, institutions, and organisations at the international, national, and local level. The MOW collaborates with other organisations, including the Prime Minister's Office, Regional Administration and Local Government (PMOLARG), Regional Administrative Secretary, Regional Water Advisory Council, and local government organisations such as district councils, district water engineers and executive officials elected at the wards of the village ${ }^{11}$.

This suggests that potentially valuable expertise from NGOs, CSOs, private actors, and local community leaders may not be fully harnessed. According to the NAOT report (2018), the involvement of multi-stakeholders in the localisation of the SDGs has been poor (ibid, p.31), and hence their voices go unheard. Our research corroborated these claims. We found no publicly accessible feedback from stakeholder engagements and consultations (see section 5.3 below), and the so-called monitoring and evaluation contained in the VNR was very ambiguous. Various stakeholders interviewed complained that: spaces for dialogue and engagement were narrow; there was no plan detailing how, when and where stakeholders would be engaged throughout the implementation; and stakeholder collaboration events alluded to in the VNR reports were not publicly advertised, hence critical stakeholders not in receipt of this information could not engage in the process (see section 5.3 below). Despite SDG 17, partnership, being one of the nine goals prioritised in Tanzania, the government has failed to fully enact multi-stakeholder participation policy and strategy (NAOT, 2018). Consequently, the extent to which other forms of governing (network and market-based) will be integrated in SDGs governance framework remains questionable.

The barriers to multi-stakeholder partnership within an integrated governance framework in Tanzania have been attributed to the authoritarian political culture in Tanzania. It is a culture that has led the government to exert policy and regulatory controls over non-state

\footnotetext{
${ }^{10} \mathrm{https}$ //www.maji.go.tz/pages/vision-of-the-ministry

$11 \mathrm{https} / / / w w w . m a j i . g o . t z /$ pages/vision-of-the-ministry
} 
actors to frustrate them from acting as meta-governors. The establishment of boundaries between the public and private sectors have weakened the capacity of local societal actors to demand more accountability and good governance (Kelsall, 2003; Lauwo et al., 2016). This is reflected in government legislations (such as the Cybercrime Act, 2015 and NGOs Regulation, 2018) designed to censor the activities NGOs and other CSOs (see section 4). This and much accountability that remains structured through formal top-down structures of the government, has created a difficult environment for multi-stakeholder collaboration and engagement in Tanzania. The shrinking political space for NGOs, Civil Society, media and other key stakeholders, has been an obstacle towards the localisation of accountability. What we observed about the localisation process was in sharp contrast to the government's proclamations.

\subsection{Challenges encountered in multi-stakeholder partnership for the SDGs}

Meta-governance assumes that meta-governors from the public and private sectors, NGOs, CSOs and other non-state actors can work in partnership to create a new form of governance arrangement (network and market-based governance) that challenges the traditional top-down hierarchical governance structure of states (Johnston, 2015; Torfing and Triantafillou, 2013). However, creating an integrated governance for localising the SDGs proved challenging in Tanzania. As Sørensen and Torfing (2005) commented, political support for multi-stakeholder partnerships and meta-governance differs between countries, due to the different national political systems, traditions and institutions that support different forms of governance. In Tanzania, despite the government's emphasis on multi-stakeholder partnership, interviewees recalled the challenges encountered in establishing multi-stakeholder partnership within a meta-governance approach. A private sector representative stressed:

"We are not valued; my opinion is that they (i.e., the government of Tanzania) should take the SDGs and put them as part of their plans and integrate the goals and the targets with government's own goals/targets, because all the plans, strategies, etc. of the government must be part of the SDGs framework" (PSPF: Representative).

A CSO member commented how their stakeholder engagement was inadequate and frustrating:

"We have not been engaged in government decisions on the SDG framework. . . The biggest challenge on the coordination of SDGs is that there is no platform or forum which will enable different stakeholders to come together or meet to discuss and analyse the implementation and the way forward ... this however depends on the political will' (CSO: Representative 1).

The above statements suggest that institutions and procedures to enable the state to work with networks and market-based types of governance are lacking. The SDGs performance audit report confirmed this, noting how it resulted in the inadequate involvement of NGOs, think tanks, CSOs and the private sector (NAOT, 2018). A UN representative stressed:

"We are [Tanzania] yet to figure out how to establish a good platform for SDGs; this is the biggest agenda that we are going to consider for the year 2018 ... and engage other development partners, CSOs, etc. .... There is no such structure in Tanzania...I am trying to communicate with the government to help put in place such a structure for SDGs implementation, but it seems the government is not yet ready to support the idea ... so, you find efforts from different groups and movements in society are not coordinated to support the SDGs ... you see, it is common to find some groups doing one thing (e.g., focusing on one $S D G$ ) while other groups are doing something else or trying to implement the same SDGs but in a different way" (DPs: Representative 2). 
A senior government official commented:

"In terms of coordination of the SDGs framework as a country, this comes under the Ministry of Finance, but again, the government has not formulated a clear institutional framework for engaging with other stakeholders at different level in overseeing the implementation process..." (Poverty reduction unit: Representative 1).

The UN 2030 agenda stresses the importance of multi-stakeholder engagement and metagovernance approach in localising the SDGs (United Nations, 2015). Ineffective coordination and limited stakeholder participation in decision-making and implementation can indicate a governance failure to promote network and market-based governance styles (Meuleman, 2015). The Tanzanian government failure to develop a strategy for identifying key stakeholders, and establishing their roles, responsibilities, and engagement, has constrained the implementation and localisation of SDGs and decreased accountability and transparency in their regard (NAOT, 2018). This is worrying as the transformational potential of the SDG framework requires stable effective governance and systems that hold governments accountable and enhance their partnerships with other stakeholders (Beunen et al., 2017). As Heidelberg (2017, p.4) counsels, accountability 'requires a space for contestation, a political space in which choices and actions are publicly exposed with an option to make necessary and desirable adjustment.'

Thus, despite the Tanzanian government's efforts to develop national-level metagovernance structures, our interviewees indicated there was a lack of formal structures for stakeholder engagement and integration of hierarchy, network, and market-based governing of the SDGs' localisation. The lack of multi-stakeholder engagement has made it difficult for key stakeholders to meaningfully participate and, thus help mobilise CSOs and other major nonstate actors to build the required meta-governance framework. As Adger (2000) has stressed, a hierarchical institutional setting limits the potential of market-based and network governance styles. The Tanzanian government's reluctance to adopt more participatory and collaborative forms of governing, deviates from the 'leave on-one behind' principle that calls for all sectors of society to participate in implementing the SDGs (United Nations, 2015). Multi-stakeholder engagement is central to shifting from government to governance (Héritier and Rhode, 2011). Indeed, it is a core principle, not only in how the SDGs are implemented, but also how they are governed in order to promote public accountability. Unfortunately, the government has, despite its claims to the contrary, confined engagement and participation to a narrow range of stakeholders - an approach that marginalises non-state actors' input.

\subsection{Other challenges in localising the SDGs}

Data unavailability, its unreliability, poor reporting systems, insufficient budget allocations and lack of inter-departmental collaboration, have also constrained the implementation of the SDG framework. A persistent theme has been that achieving the SDGs' emancipatory potential as envisioned in the UN agenda 2030 (United Nations, 2015) requires coordination and governance systems that promote inclusive stakeholder participation, alongside a combination of different governance styles: hierarchical, network and market based (Meuleman and Niestroy, 2015). However, while Tanzania's government acknowledges the possible gaps and challenges in its localisation of SDGs, its public pronouncements have claimed that the project is being taken forward within a strong governance framework. For example:

The country has robust development frameworks being supported by policies, plans and strategies, as well as a legal framework for the implementation of the country's development agenda in general and the SDGs in particular. The supportive environment for implementing the SDGs in Tanzania is strong. This notwithstanding, gaps and 
challenges still exist that need to be addressed for the country to realize the SDGs targets $\operatorname{set}^{12}$.

By contrast, the performance audit report on SDGs (NAOT, 2018) identified the lack of institutional structures for integrating SDGs into the national development plan as the main constraint for their localisation:

MoFP did not set an institutional mechanism to integrate SDGs into the national actions. .... although the Planning Commission, MoFP-PED and NBS are carrying out activities related to SDGs, there is no cabinet directive which mandates them to that effect. ...although PED undertook the activities related to SDGs particularly public awareness creation on SDGs, they are only responsible with goals related to poverty eradication. This is because there is no policy directive showing which institution is solely responsible for dealing with SDGs integration in general. This may cause other SDGs not to effectively be integrated to national actions thereby inadequate implementation which may not achieve the set goals and targets (ibid., p.20).

Zarrouk $(2014$, p.2) has argued that 'a vision of capacity building at all levels and institutional building is vital to transform governance and ensure that it serves the needs of sustainable development particularly in DCs'. The United Nations (2015) has argued that more local data should be accessed and collected to measure progress in service delivery; and communities must be sensitised to the SDGs' importance generally and locally. However, some interviewees complained about the complexity of localising the SDG framework and reporting progress on its achievement, given the problems surrounding data availability and reliability. A government official commented:

"Data availability is a key problem in the implementation of the SDGs framework. It takes so long sometimes; for example, an iterated labour survey that was meant to be conducted in 2007 was conducted in 2014, it also takes a long time to prepare a summary of the survey, this is also linked to the finance problem... the survey is very expensive ... with regard to the poor quality of data collected at the MoFP, we know the progress (i.e. of improving the quality of SDGs data/statistics collection) is slow, but we know we will reach our goal ... there is a significant lack of financial resources ... we will continue to reduce this data gap problem ... by cooperating with other institutions/organisations" (MoFP-PED: Representative 2).

Similarly, Tanzania's performance audit report on SDGs (NAOT, 2018) noted the lack of systems to monitor, review and report on the implementation of the SDGs framework, stating that:

NBS had inadequate capacity for data collection, posing a challenge on the timely and quality availability of data required for tracking the progress implementation of the FYDP II and SDGs. Further, the system for data collection and analysis is not harmonised due to lack of clear link between NBS the custodian of the national data on one hand and MDAs and LGAs on the other hand. The system used by the MDAs and LGAs is not compatible to that of NBS making data sharing difficult between those institutions (p.47).

A UN representative reiterated how the lack of reporting and accountability systems has constrained the implementation of the SDGs:

"Accountability and reporting are the major challenges of SDGs in the country ...I am not sure about who will prepare the report and the format of the SDGs framework implementation/progress for submission to the international organisations ... what I

\footnotetext{
12 https://www.nbs.go.tz/index.php/en/sdg/428-voluntary-national-review-vnr-2019-empowering-people-andensuring-inclusiveness-and-equality
} 
know is that the NBS is currently leading the data collection ..." (DPs: Representative 2).

A government official expressed similar frustrations over the lack of reporting systems and the difficulty in accurately measuring achievement with regards to the SDGs framework accurately:

'SDGs' reporting platform is yet to be completed; it may be difficult to have accurate statistics of how far we are in terms of attainment of the SDGs framework.... We are in the process of preparing a SDGs' mobilisation portal .... We have only prepared a baseline report based on a survey report of NSGRP 2015. As a country, we wish to have a report every two years, but this is a big challenge for us now... We have a lot of other reporting commitment as a country (e.g., reports for Africa 2060, SADEC, EAC, etc.) ... We have freedom to prioritise what is important to us and reporting is still voluntary" (MoFP-PED: Representative 1).

These problems are symptomatic of local governance challenges in Tanzania. Any implementation of the SDGs and their localisation needs budgetary provision at the national and, where possible, the local level (Meuleman, 2015). However, another government official expressed frustration over this:

". . . because of budgetary constraints we have not been able to move to the next stage, helping LGAs understand how to integrate the SDGs framework in their planning, budgeting and operations..." (MoFP-PED: Representative 2).

The performance audit report on SDGs (NAOT, 2018) also noted the lack of budgetary allocations to operationalise the framework:

According to the review of national annual budget 2016/2017 and 2017/2018 together with the budget speech of the Minister of Finance and Planning, the audit noted that MoFP did not align the costs of operationalizing SDGs policy settings with the national budget. Officials from MoFP- Budget Department confirmed that neither MoFP nor PORALG submitted budget proposal for SDGs framework . . . Because of this the ministries had not secured funding for operationalising of the SDGs framework (ibid, p.23).

Also, the need for inter-departmental cooperation has increased the complexity of localising and measuring the SDGs framework, as a government official recognised:

"In order to establish a nationally and internationally recognised formal standard of recording and reporting, we will have to meet with the NBS to agree on the performance indicators, and the format of SDG framework implementation, progress, and performance/achievement reporting to be used" (POPC: representative).

Thus, the Tanzanian government's efforts to localise the SDGs, have been undermined by several factors. Despite its efforts to develop targets, performance measurement, budget allocations and other technologies to monitor and account for progress, data availability, its unreliability, poor reporting systems, insufficient budget allocations, and the need for better inter-departmental collaboration have proven to be hindrances. Successfully implementing the SDGs framework in a DC needs political commitment and strong national governance structures. These structures have not been in place in Tanzania (Horn and Grugel, 2018). 


\section{Conclusion}

The analysis used the shift from government to governance to meta-governance framework (Johnston, 2015; Klijn, 2008; Gjaltema et al., 2020; Rhodes, 2007; Rhodes 1997, 2007; Bevir, 2006) to examine the governance of the SDGs framework in Tanzania. The shift from government to governance work identifies the need to involve both state and non-state actors in localising SDGs. The meta-governance approach suggests that different modes of governance, such as hierarchy or market (beside networks) may influence relations and shape interactions between these actors (Sorensen \& Torfing, 2005; Meuleman, 2008). Drawing upon this perspective helped us to identify and conceptualise: the shift from government to governance; the need to replace traditional hierarchical top-down modes of governance and accountability with multi-stakeholder engagement and collaboration involving state and nonstate actors, consistent with the UN agenda (United Nations, 2015); and the combining of different governance styles in implementing SDGs.

The state is a key actor in determining the national governance mechanisms that underpin accountability at the local level (cf. United Nations, 2015), and the relationship between state and non-state actors and nature of governing styles (Sorensen \& Torfing, 2005). For example, a governance system prevalent in developed countries, where non-state actors (such as the private sector, NGOs and other CSOs) significantly influence policy making and decisions, can differ from DCs like Tanzania, where decision making often prevails in a centralised top-down hierarchical structure that gives little space to network and market-based governance forms (cf. Tadesse and Steen, 2020).

Nevertheless, we found that the socio-political context in Tanzania, possibly as in some other DCs, differs in how it has shaped multi-stakeholder engagement and the different governing styles required for localising the SDGs. Proponents of a meta-governance approach to SDG implementations (United Nations, 2015), have neglected the problems that local NGOs, CSOs and other non-state actors face in acting as meta-governors in DCs and Tanzania in particular, e.g. a lack of capacity, harsh regulatory controls and an unsympathetic political environment (Kelsall, 2003; Human Rights Watch, 2019). The limited involvement of different meta-governors, and network and market-based governance arrangements, can have severe implications in realising the SDGs in Tanzania in particular and by extension, in other DCs.

The empirical analysis found that the Tanzanian Government has established a nationallevel meta-governance system. However, key stakeholders, such as CSOs and NGOs, have cast doubt on its effectiveness, pointing to the lack of effective institutional coordination systems to facilitate collaborative engagement with them. For example, currently there is no specific strategy or legal framework to support the implementation of the SDGs framework, and its governance resides within the existing hierarchical top-down governance structures, which neglects other potentially important forms of governance such as networks and markets. As Kooiman (2003) and Sørensen (2006) argue, new governing arrangements are often developed in the shadow of hierarchy (Kooiman, 2003; Sørensen, 2006). The analysis also highlighted that the Tanzanian government has prioritised issues that are prominent in the national development plan and inevitably neglected some important SDGs, including goal 8, Decent work and economic growth; goal 10, Reduce inequalities within and amongst countries; goal 13, Climate Action; goal 14, Life below water; and goal 15 Life on land, which were not deemed to be national priorities.

The paper makes three key contributions to the accounting literature. First, it extends the literature on governance and sustainability (Bebbington and Unerman, 2018; Bebbington et al., 2017; Charnock and Keith, 2020; Rosati and Faria, 2019; Spence and Rinalidi, 2014) by bringing insights from a DC, namely Tanzania, on the nature of accountability and governance mechanisms at the national level and the complexity of attempting to adopt an integrated approach to governance in implementing the SDGs. Second, it contributes to the limited 
literature that explores the relationship between governance and accountability in the pursuit of the SDG agenda (Abhayawans et al., 2021; Meuleman, 2018), and the meta-governance challenges encountered (Bebbington and Unerman, 2018; Charnock and Hoskin, 2020; Hopper, 2019; Niles and Moore, 2021; Sobkowiak et al., 2020). We extend this literature by showing how the governance system and local context in Tanzania has shaped the interactions between state and non-state actors, modes of governing, and mechanisms for ensuring accountability towards the realisation of the SDGs agenda differently from what is recommended by many scholars and international agencies. Although the promoters of the SDGs emphasise the need for collaborative governance networks and market-oriented policies, our evidence shows that implementation of SDGs in Tanzania remains rooted within the government's hierarchical governance structure and top-down accountability. The Tanzanian government's failure to enact a multi-stakeholder partnership strategy or policy and its neglect of some SDGs, raises questions on the possibility of realising the SDGs by 2030 in Tanzania. This may be therefore true for other DCs having a similar political context. Third, we aspire to contribute to the use of from government to governance (Rhodes, 1997, 2007) to metagovernance (Gjaltema et al., 2020) perspective in accounting literature. Drawing on government to governance and meta-governance literature helped us to diagnose how the regulatory, institutional, and political environment in Tanzania, has shaped multi-stakeholder interaction and involvement on the one hand and accountability and governance on the other. Despite the pivotal role of CSOs and other non-state actors in meta-governance, their efforts and ability to monitor and demand accountability from the government with regards to the implementation of the SDGs in Tanzania, has been constrained by the political context and the regulations intended to side-line them. As Pattberg and Widerberg (2014) note, multistakeholder partnership is embedded in a political and social context that will influence their chances to thrive.

SGDs are undoubtedly a 'political project' and require political shepherding and direction to be achieved. But, consistent with many other scholars, we believe that implementation should be inclusive and participatory, consistent with the core principle of "leaving no-one behind" whereby a wide variety of state and non-state actors can contribute according to their strengths and interests. If undertaken in such a manner, the localisation of the SDGs requires and should foster transparency and accountability. However, there is a paucity of empirical research on the obstacles to this in DCs. For example, this study found that the government of Tanzania, in addition to adopting more tangible SDG-friendly policies, needs to undertake practical steps to devise strategies and plans for financial resources, stakeholder engagement, and governance and accountability that are specific to each SDG. It also needs to strengthen related institutional structures and related governance arrangement, in order to help realise the SDGs framework. More theoretical and empirical evidence is needed on these issues as are the disclosure practices of governments and their agencies on individual SDGs in DCs. More research is also needed on the role of performance measurement technologies such as accounting, budgeting and auditing for supporting the realisation of the SDGs framework. 


\section{References}

Abhayawansa, S., Adams, C.A, and Neesham, C. (2021), "Accountability and governance in pursuit of Sustainable Development Goals: conceptualizing how governments create value, Accounting, Auditing \& Accountability, Vol.34, No.4, pp. 923-945.

Abrahamsen, R. (2000), Disciplining Democracy: Development Discourse and Good Governance in Africa, Zed Books, London

Adger WN. 2000. Institutional adaptation to environmental risk under the transition in Vietnam. Annals of the Association of American Geographers, Vol.90, No.4, pp.738-758

Almqvist, R., Grossi, G., Van Helden, G.J. and Reichard, C., 2013. Public sector governance and accountability. In Critical Perspectives on Accounting, Vol.7, No., pp.479-487.

Aucoin, P. and Jarvis, M., (2005). Modernizing Government Accountability: A Framework for Reform. Ottawa: Canada School of Public Service.

Amnesty, I. (2019) The Price We Pay: Targeted for Dissent by the Tanzanian State", available at: $\quad$ https://www.amnesty.org/download/Documents/AFR5603012019ENGLISH.pdf, (accessed 12/09/2020).

Arora, M. P., and Lodhia, S. (2017), "The BP Gulf of Mexico oil spill: Exploring the link between social and environmental disclosures and reputation risk management". Journal of Cleaner Production, Vol. 40, No. 140, pp.1287-1297.

Bakre, O., Lauwo, S.G. and McCartney, S. (2017), "Western accounting reforms and accountability in wealth redistribution in patronage-based Nigerian society", Accounting, Auditing \& Accountability Journal, 30(6): 1288-1308.

Barrett, F. S., Doss, M.K, Sepeda, N.D., Pekar, J.J., and Griffiths, R.R. (2020), "Emotions and brain function are altered up to one month after a single high dose of psilocybin", Scientific Reports 10 (1), available at https://jhu.pure.elsevier.com/en/publications/emotions-and-brainfunction-are-altered-up-to-one-month-after-a-s/fingerprints/.

Bayart, J. F. (2009), The State in Africa: The Politics of the Belly, Polity Press, Cambridge.

Bebbington, J., Russell, S., and Thomson, I. (2017), "Accounting and sustainable development: Reflections and propositions", Critical Perspectives on Accounting, Vol. 48:21-34.

Bebbington, J., and Unerman, J. (2018), "Achieving the United Nations Sustainable Development Goals: An enabling role for accounting research", Accounting, Auditing and Accountability Journal, Vol. 31, No. 1, pp. 2-24.

Bebbington, J., and J. Unerman. (2020), "Advancing research into accounting and the UN Sustainable Development Goal", Accounting, Auditing \& Accountability Journal, Vol. 33 No. 7, pp. 1657-1670.

Beisheim, M., A. Ellersiek, L. Goltermann, and P. Kiamba. (2018), "Meta-Governance of Partnerships for Sustainable Development: Actors' Perspectives from Kenya", Public Administration and Development, Vol. 38, No. 3, pp. 105-119.

Bell, S., and Park, A. (2006) "The problematic metagovernance of networks: Water reform in New South Wales", Peace Research Abstracts Journal, Vol. 43, No. 6. 
Beunen, R., Patterson, J., and Van Assche, K. (2017), "Governing for resilience: the role of institutional work", Current Opinion in Environmental Sustainability, Vol. 28, pp. 10-16.

Bevir, M. (2006), "Democratic Governance: Systems and Radical Perspectives", Public Administration Review, Vol. 66, No. 3, pp. 426-436.

Bevir, M. (2010), "Interpreting Territory and Power", Government and Opposition, Vol. 45 , No. 3, pp. 436-456.

Bevir, M. (2011), "Governance and governmentality after neoliberalism", Policy \& Politics Vol. 39, No. 4, pp. 457-471.

Biermann, F., Kim, R.E., and Kanie, N. (2017), "Global governance by goal setting: the novel approach of the UN Sustainable Development Goals", Current Opinion in Environmental Sustainability, Vol. 26, No. 27, pp. 26-31.

Boas, I., Biermann, F., and Kanie, N. (2016), "Cross-sectoral strategies in global sustainability governance: towards a nexus approach", International Environmental Agreements: Politics, Law and Economics, Vol. 16, No. 3, pp. 449-464.

Boncodin, E.T. (2007), "Citizen Engagement in budgeting and public accountability", paper presented at the 6th Session of the United Nations Committee of Experts on Public Administration, New York, NY, 10-14 April.

Bowen, K. J., Cradock-Henry, N.A, Koch, F., Patterson, J. T. Häyhä, T., Vogt, J., and Barbi. F. (2017), Implementing the "Sustainable Development Goals": towards addressing three key governance challenges - collective action, trade-offs, and accountability", Current Opinion in Environmental Sustainability, Vol. 26, No. 27, pp. 90-96.

Broadbent, J., \& Guthrie, J. (2008). Public sector to public services: 20 years of "contextual" accounting research. Accounting, Auditing \& Accountability Journal, Vol. 21 No. 2, pp. 129169.

Breuer, A., \& Leininger, J. (2021). Horizontal Accountability for SDG Implementation: A Comparative Cross-National Analysis of Emerging National Accountability Regimes. Sustainability, Vol.13, No.13,pp. 7002.

Business Times, (2001a). Debt relief too little to impact on poverty. 10th August, Dar es Salaam.

Business Times, (2001b). Tanzanian NGOs make money from waste. 3rd August, Dar es Salaam

Chachage, C. S. L. (2003), Globalization and Democratic Governance in Tanzania. Addis Ababa: Development Policy Management Forum, available at: https://sarpn.org/documents/d0002374/Globalization_Tanzania_DPMF_2003.pdf.

Charnock, R., and Hoskin, K. (2020), "SDG 13 and the entwining of climate and sustainability meta-governance: an archaeological-genealogical analysis of goals-based climate governance", Accounting auditing \& accountability Journal , Vol. 33, No. 7, pp. 1731-1759.

Christopoulos, S., B. Horvath, and M. Kull. (2012), "Advancing the Governance of CrossSectoral Policies for Sustainable Development: A Meta-governance Perspective", Public Administration and Development, Vol. 32, No. 3, pp. 305-323. 
Financial Times (2001), Editorial comment - Consultative Group Meetings: elitist or people centred? 12- 18th September, Dar es Salaam.

Fischer, M., Nguyen, M., and Strande, L. (2019), "Context matters: horizontal and hierarchical network governance structures in Vietnam's sanitation sector", Ecology and Society, Vol. 24 No. 3 .

Fransen, L. (2015), "The politics of meta-governance in transnational private sustainability governance", Policy Sciences, Vol. 48, No. 3, pp. 293-317.

Gabay, C., and Ilcan, S. (2017), " Leaving No-one Behind? The Politics of Destination in the 2030 Sustainable Development Goals", Globalizations, Vol. 14, No. 3, pp. 337-342.

Gjaltema, J., Biesbroek, R., and Termeer, K. (2020). "From government to governance...to meta-governance: a systematic literature review", Public Management Review, Vol. 22, No. 12, pp. $1760-1780$.

Glass, L.M., and Newig, J. (2019), "Governance for achieving the Sustainable Development Goals: How important are participation, policy coherence, reflexivity, adaptation and democratic institutions"?, Earth System Governance, Vol. 2, p. 100031.

Goddard, A. (2005). Accounting and NPM in UK local government-contributions towards governance and accountability. Financial Accountability \& Management, Vol.21 No., pp.191218.

Gray, R., Owen,D., Adams, C., (1996), Accounting and accountability: Changes and challenges in corporate social and environmental reporting, Prentice-Hall, London.

Gupta, J., \& Nilsson, M. (2017). "Toward a Multi-level Action Framework for Sustainable Development Goals", in Kanie, N. \& Biermann, E., (eds), Governing through goals: Sustainable Development Goals as governance innovation, pp.275-291.

Harrison, G. (2008), "From the global to the local?: governance and development at the local level: reflections from Tanzania", Journal of Modern African Studies, Vol. 46, No. 2, pp. 169189.

Harrison, G., Mulley, S., (2007), Tanzania: A Genuine Case of Recipient Leadership in the Aid System? In the Edited Whitfield, L., (ed) The politics of aid: African strategies for dealing with donors., London, Oxford University Press.

Haveri, A., Nyholm, I., Røiseland, A., and Vabo, I. (2009), "Governing Collaboration: Practices of Meta-Governance in Finnish and Norwegian Local Governments", Local Government Studies, Vol. 35, No. 5, pp. 539-556.

Heidelberg, R. L. (2017), "Political Accountability and Spaces of Contestation", Administration \& Society, Vol. 49, No.10, pp. 1379-1402.

Héritier, A. W., and Rhodes, M. (2011), New Modes of Governance in Europe: Governing in the Shadow of Hierarchy. Palgrave Macmillan, London.

Hopper, T. (2019), "Stop Accounting Myopia: - think globally: a polemic", Journal of Accounting \& Organizational Change, Vol. 15, No. 1, pp. 87-99. 
Horn, P., and Grugel, J. (2018) "The SDGs in middle-income countries: Setting or serving domestic development agendas? Evidence from Ecuador", World Development, Vol. 109, pp. 73-84.

Human Rights Watch (2019), ' As Long as I am Quiet, I am Safe': Threats to Independent Media and Civil Society in Tanzania, Threats to Independent Media and Civil Society in Tanzania | HRW(accessed on 25/02/2021).

Hydén, G., Court, J., and Mease, K. (2004), Making Sense of Governance: Empirical Evidence from Sixteen Developing Countries, Boulder: Lynne Rienner.

Jarvis, M.D., (2004), “Hierarchical Accountability”, in Boven, M., Goodin, R.E., \& Chillemans T., (eds), The Oxford handbook of public accountability, pp.405-420.

Jessop, B. (2003), "Governance and Metagovernance: On Reflexivity, Requisite Variety, and Requisite Irony", Governance as Social and Political Communication, pp. 101-116.

Jessop, B. (2011), "Multilevel governance and multilevel metagovernance. Changes in the EU as integral moments in the transformation and reorientation of contemporary statehood", in Ian, B. and Matthew, F. (Eds), Multi-Level Governance, Oxford University Press, Oxford; New York, pp. 49-74.

Johnston, K. (2015)," Public governance: the government of non-state actors in "partnerships", Public Money \& Management, Vol. 35, No.1, pp. 15-22.

Kelsall, T. (2002), "Shop windows and smoke-filled rooms: governance and the repoliticization of Tanzania", The Journal of Modern African Studies, Vol.40, No. 4, pp. 597619.

Kelsall, T. (2003) Donors, NGOs \& the State: Governance \& 'civil society' in Tanzania." in Booth, D., Dietz, A.J., Golooba-Mutebi, F., Fuady, A.H, Henley, D., Kelsall, T., A.H.M. Leliveld, A.H.M., and van Donge,J.K, Developmental Regimes in Africa synthesis report, ODI: London

Klein, E., and Koppenjan, J. (2014), Accountable networks. In The Oxford Handbook of Public Accountability; Bovens, B., Goodin, R.E., Schillemans, T., Eds.; Oxford University Press: Oxford, 2014; pp. 242-257

Klijn, E.H. (2008), "Complexity Theory and Public Administration: What's New? Key concepts in complexity theory compared to their counterparts in public administration research", Public Management Review, Vol. 10, No. 3, pp. 299-317.

Kooiman, J. (1993), Modern Governance: New Government-Society Interactions. SAGE Publications, London.

Kooiman, J. (2003) Governing as Governance. SAGE Publications, London

Kooiman, J., and van Vliet, M. (2000), "Self-Governance as a Mode of Societal Governance", Public Management: An International Journal of Research and Theory, Vol. 2, No. 3, pp. 359378. 
Larsson, O. L. (2017), "Meta-Governance and Collaborative Crisis Management - Competing Rationalities in the Management of the Swedish Security Communications System", Risk, Hazards Crisis Public Policy Risk, Hazards and Crisis in Public Policy, Vol. 8, No.4, pp. 312334.

Lauwo, S. G., Otusanya, O. J., and O. Bakre, O. (2016), "Corporate Social Responsibility Reporting in the Mining Sector of Tanzania: (Lack of) Government Regulatory Controls and NGO Activism", Accounting, Auditing \& Accountability Journal , Vol. 29, No. 6.

Maeda, R. A., and Chacha, S. (2019). "Tanzania civil society report on the sustainable development goals: contribution to the voluntary national review 2019: Tanzania Sustainable Development, Platform. Available at: https://searchworks.stanford.edu/view/13675928.

Martinez, D. E., \& Cooper, D. J. (2017). "Assembling international development: Accountability and the disarticulation of a social movement". Accounting, Organizations and Society, Vol.63,pp. 6-20.

Mashindano, S., and Baregu, S. (2016), "National Level Implications of Implementing the SDGs in Tanzania", Southern Voice, available at: http://southernvoice.org/national-levelimplications-of-implementing-the-sdgs-in-tanzania/.

Messner, M., (2009). The limits of accountability. Accounting, Organizations and Society, 34(8), pp.918-938.

Meuleman, L. (2008), Public Management and the Meta-governance of Hierarchies, Networks and Markets: The feasibility of designing and managing governance style combinations; Erasmus University, Rotterdam.

Meuleman, L., and Niestroy, I. (2015), "Common But Differentiated Governance: A Metagovernance Approach to Make the SDGs Work, Sustainability, Vol. 7, No. 9, pp. 12295-12321.

Meuleman, L. (2018), Meta-governance for Sustainability: A Framework for Implementing the Sustainable Development Goals, Routledge, London.

Mulgan, R. (2000). 'Accountability': An ever-expanding concept? Public administration, Vol.78, No.3,pp. 555-573.

Müller, J. (2006), Reforming the United Nations: The Struggle for Legitimacy and Effectiveness. Brill, Amsterdam.

Niles, K., and Moore, W. (2021), "Accounting for Environmental Assets as Sovereign Wealth Funds", Journal of sustainable finance \& investment, Vol. 11, No. 1, pp. 62-81.

O'Dwyer, B., \& Owen, D. L. (2005). Assurance statement practice in environmental, social and sustainability reporting: a critical evaluation. The British Accounting Review, Vol. 37, No.2, pp.205-229.

Pahl-Wostl, C., Conca, K., Kramer, A., Maestu, J., and Schmidt, F. (2013), "Missing Links in Global Water Governance: a Processes-Oriented Analysis", Ecology and Society, Vol. 18, No. 2.

Pattberg, P., and Widerberg, O. (2014), "Transnational Multi-Stakeholder Partnerships for Sustainable Development: Building Blocks for Success", SSRN Electronic Journal. VU University Amsterdam - Institute for Environmental Studies (IVM). 
Parker, L., \& Gould, G. (1999, June). Changing public sector accountability: critiquing new directions. In Accounting forum, Vol. 23, No. 2, pp. 109-135.

Pierre, J., and Peters, B.G. (2005), Governance, Politics, and the State. MacMillan Press, New York, NY.

Rasheed, A. A. 2020. Framing Meta-governance in the Context of Developing Democracies: An Institutionalist Viewpoint. Journal of Public Administration and Governance, Vol.10, No. 3, p. 91 .

Rhodes, R. A.W. (1992), "New Directions in the Study of Policy Networks", European Journal of Political Research, Vol. 21, No. 1-2, pp. 81-205.

Rhodes, R. A.W. (1997), Understanding Governance: Policy Networks, Governance, Reflexivity and Accountability. Open University Press, Maidenhead.

Rhodes, R.A.W. (2007), "Understanding Governance: Ten Years On", Organization Studies, Vol. 28, No. 8, pp. 1243-1264.

Roberts, J., (1991), "The possibilities of accountability", Accounting, Organizations and Society Journal, Vol.16, No.4, pp. 355-368

Rodić, L., and Wilson, D. (2017), "Resolving Governance Issues to Achieve Priority Sustainable Development Goals Related to Solid Waste Management in Developing Countries", Sustainability, Vol. 9, No. 3, p. 404.

Rosati, F., and Faria, L. G. D. (2019), "Business contribution to the Sustainable Development Agenda: Organizational factors related to early adoption of SDG reporting, Corporate Social Responsibility and Environmental Management, Vol. 26, No. 3, pp. 588-597.

Rosenau, J. N. (1992), Governance Without Government: Order and Change in World Politics, Cambridge University Press, Cambridge.

Rothstein, B. (2011), The Quality of Government: Corruption, Social Trust, and Inequality in International Perspective. University of Chicago Press, Chicago.

Sketcher, C., Mathur, N., and Smith, M. (2005), "The Public Governance of Collaborative Spaces: Discourse, Design and Democracy, Public Administration, Vol. 83, No. 3, pp. 573-96.

Spence, L. J., \& Rinaldi, L. (2014). Governmentality in accounting and accountability: A case study of embedding sustainability in a supply chain. Accounting, Organizations and Society, Vol. 39, No. 6, pp.433-452.

Sobkowiak, M., Cuckston, T., and I. Thomson, I. (2020), "Framing sustainable development challenges: accounting for SDG-15 in the UK". Accounting, Auditing \& Accountability Journal Vol. 33, No. 7, pp. 1671-1703.

Sørensen, E. (2006), "Meta-governance: The Changing Role of Politicians in Processes of Democratic Governance. The American Review of Public Administration, Vol. 36, No. 1, pp. 98-114.

Sørensen, E., and Torfing, J. (2005), The Democratic Anchorage of Governance Networks" Scandinavian Political Studies, Vol. 28, No. 3, pp. 195-218.

Sørensen, E., and Torfing, J. (2007), Theories of Democratic Network Governance. Palgrave Macmillan, New York. 
Sørensen, E., and Torfing, J. (2009), "Making governance networks effective and democratic through meta-governance", Public Administration, Vol. 87, No. 2, pp. 234-258.

Stoker, G. (1998), "Theory and Urban Politics", International Political Science Review, Vol. 19, No.2. pp. 119-129.

Tadesse, H., \& Steen, T. (2020). Multi-Stakeholder Partnership for Health Service Delivery in the Context of Developmental State: The Ethiopian Experience, in Debela, B.K., Bouckaert, G., Warota, M.A., \& Gemechu, D.F. (eds), Public Administration in Ethiopia:Case Studies and Lessons for Sustainable Development, pp.85-112, Leuven University Press

Todd, G., M. Mamdani, M. (2017), "Tanzania and the Sustainable Development Goals: Has Tanzania prepared to roll-out and domesticate the health SDGs?", The Graduate Institute Geneva, Available at: http:/ghptt.graduateinstitute.ch/documents/tanzania-and-sustainabledevelopment-goals-has-tanzania-prepared-roll-out-and-domesticate

Torfing, J., Peters, B.G., Pierre, J., and Sørensen, E. (2012), Interactive Governance: Advancing the Paradigm, Open University Press, Regent's Place, London.

Torfing, J., and Triantafillou, P. (2013), What's in a Name? Grasping New Public Governance as a Political-Administrative System. International Review of public administration, Vol.18, No. 2, pp. 9-25.

United Nations (2015), "Transforming our world: the 2030 Agenda for Sustainable Development - A/RES/70/1: Resolution adopted by the General Assembly on 25 September 2015". United Nations (UN) Sustainable Development Knowledge Platform, available at: https://sustainabledevelopment.un.org/post2015/transformingourworld.

United Nations (2018), "World Economic Situation and Prospects 2018". United Nations (UN) Department of Economic and Social Affairs (UN/DESA) in collaboration with other UN and regional organizations, available at: https://www.un.org/development/desa/dpad/wp content/uploads/sites/45/publication/WESP2018_Full_Web-1.pdf.

United Nations (2019), "The Sustainable Development Goals Report - 2019". United Nations (UN). available at: https://unstats.un.org/sdgs/report/2019/The-Sustainable-DevelopmentGoals-Report-2019.pdf.

UNDP (2016), "Human development report, 2016: Human development for everyone.". United Nations Development Programme, available at: http://hdr.undp.org/sites/default/files/2016_human_development_report.pdf [accessed 23/10/2019).

UNDP (2017), "Tanzania Human Development Report 2017: Social Policy in the Context of Economic Transformation', Economic and Social Research Foundation". United Nations Development Programme, available at: http://hdr.undp.org/sites/default/files/thdr2017launch.pdf (accessed 12/05/2019).

UNDP (2019), "Human Development Report, 2019-Beyond income, beyond averages, beyond today: Inequalities in human development in the 21 st century". United Nations Development Programme, available at: http://hdr.undp.org/sites/default/files/hdr2019.pdf.

UNRISD (2016), "Policy Innovations for Transformative Change: Implementing the 2030 Agenda for Sustainable Development". United Nations Research Institute for Social Development

(UNRISD). available

at: 
http://www.unrisd.org/UNRISD/website/projects.nsf/(httpProjects)/AC3E80757E7BD4E9C1 257F310050863D?OpenDocument.

URT (2011), "National Five-Year Development Plan I (FYDP II): 2011/12 - 2015/16", "Unleashing Tanzania's Latent Growth Potentials". Ministry of Finance and Planning (MoFP), June 2011, United Republic of Tanzania (URT). available at: http://extwprlegs1.fao.org/docs/pdf/tan151051.pdf (accessed 25/04/2018).

URT (2016), "National Five-Year Development Plan II (FYDP II): 2016/17 - 2020/21", "Nurturing Industrialization for Economic Transformation and Human Development". Ministry of Finance and Planning (MoFP), June 2016, United Republic of Tanzania (URT). available at: http://www.mof.go.tz/mofdocs/msemaji/Five\%202016_17_2020_21.pdf (accessed 25/04/2018).

URT. (2019a), "Implementation Status of SDGs Indicators in Tanzania Framework", National Bureau of Statistics (NBS). Available at: https://www.nbs.go.tz/nbs/takwimu/SDGs/SDGs_Indicators_in_Tanzania_Framework.pdf (accessed 30/06/2020).

URT (2019b), "Voluntary National Review (VNR): A Report on the Progress of the Sustainable Development Goals (SDGs) Implementation in the United Republic of Tanzania", United Nations, SDGs Knowledge Platform, available at: https://sustainabledevelopment.un.org/memberstates/tanzania.

Voluntary National Review (2019), Empowering People and Ensuring Inclusiveness and Equality", (a report on the progress of Sustainable Development Goals (SDGs) Implementation in the United Republic of Tanzania; submitted to the High-Level Political Forum (HLPF), United Nations)), available at: https://sustainabledevelopment.un.org/content/documents/23429VNR_Report_Tanzania_201 9_FINAL.pdf.

Whitehead, M. (2003), 'In the Shadow of Hierarchy': Meta-Governance, Policy Reform and Urban Regeneration in the West Midlands. Area, Vol. 35, No.1, pp. 6-14.

Woolgar, S., and Neyland, D. (2013), Mundane Governance: Ontology and Accountability, Oxford University Press, Oxford, London.

World Bank (1989), Sub-Saharan Africa: from crisis to sustainable growth: a long-term perspective study: publication summary. Washington, D.C.: World Bank.

World Bank (2019), "Tanzania Economic Update, July 2019: Human Capital - The Real Wealth of Nations", The World Bank 2019, available at: http://elibrary.worldbank.org/doi/book/10.1596/32177. 


\section{Manuscript ID AAAJ-10-2019-4220: Changing the game or more of the same? Accountability and governing in localising the Sustainable Development Goals in a developing country- Tanzania}

We are again very grateful for your detailed reading of the paper and comments which have been useful in revising and improving this paper further.

a) The abstract is relatively large and lacks readability.

Response: Thank you for the important comment. Following your advice we have carefully revised the abstract and the entire paper. The abstract has been substantially revised and reduced. We hope this provides more clarity and is more succinct.

b) Typos can be easily fixed: for example, 'localization2' (p3) should be 'localization'; 'UNDP, 2015l' (p.3) should be 'UNDP 2015'; 'Decent wok' (p4) should be 'Decent work'. Read the entire paper carefully.

Response: Thank you very much for the important observation and suggestions. Following your advice we have carefully revised the entire paper and corrected the typos.

c) Table 3 (P.6) has a structure problem: what does the column represent? And what does the row represent? There is room to make the table comprehensive.

Response: Thank you for this insightful comment. Following your suggestion, we have provided some clarifications to make this more comprehensive and understandable. For example, page of the revised paper now states: Table 3 summarises the main features and major differences of forms of governance (government, governance and meta-governance). It shows the characteristics of key governance dimension and properties from the perspective of these different governance styles.

d) 'Research Methodology and methods' (p. 11): in this section title, are research methodology and methods together? It seems to me narratives and descriptions of this section are all about the research method.

Response: This has been revised to reflect the suggestion

e) 'Analysis of empirical findings' (p. 14): You have provided findings and then analysis. You could consider changing the section title to 'Findings and analysis'.

Response: Thank you for your comment. This has now been changed to "Findings and analysis".

Overall, we would like to thank you for your valuable suggestions which have been very helpful in developing our thoughts further and in writing a more coherent, structured and focused paper. 